\title{
Seismoturbidite record as preserved at core sites at the Cascadia and Sumatra-Andaman subduction zones
}

\author{
J. R. Patton ${ }^{1}$, C. Goldfinger ${ }^{1}$, A. E. Morey ${ }^{1}$, C. Romsos $^{1}$, B. Black ${ }^{1}$, Y. Djadjadihardja ${ }^{2}$, and Udrekh ${ }^{2}$ \\ ${ }^{1}$ College of Oceanic and Atmospheric Sciences, Oregon State University, Corvallis, OR 97331, USA \\ ${ }^{2}$ Bandan Penghajian Dan Penerapan Teknologi BPPT 2nd Building, 19th Floor, Jl.MH. Thamrin 8, Jakarta, 10340, Indonesia
}

Correspondence to: J. R. Patton (quakejay@gmail.com)

Received: 27 February 2012 - Published in Nat. Hazards Earth Syst. Sci. Discuss.: Revised: 4 October 2012 - Accepted: 14 December 2012 - Published: 4 April 2013

\begin{abstract}
Turbidite deposition along slope and trench settings is evaluated for the Cascadia and Sumatra-Andaman subduction zones. Source proximity, basin effects, turbidity current flow path, temporal and spatial earthquake rupture, hydrodynamics, and topography all likely play roles in the deposition of the turbidites as evidenced by the vertical structure of the final deposits. Channel systems tend to promote low-frequency components of the content of the current over longer distances, while more proximal slope basins and baseof-slope apron fan settings result in a turbidite structure that is likely influenced by local physiography and other factors. Cascadia's margin is dominated by glacial cycle constructed pathways which promote turbidity current flows for large distances. Sumatra margin pathways do not inherit these antecedent sedimentary systems, so turbidity currents are more localized.
\end{abstract}

\section{Introduction}

Sedimentation of active margins is commonly dominated by turbidite systems. During sea level high stands, or for regions isolated from terrestrial sedimentation processes, these systems may principally be driven by seismic cycles (Nelson et al., 2011; Goldfinger et al., 2012). Accretionary prism architecture provides a first order control on flow paths for mass wasting processes (Bouma, 2004; Bouma et al., 2006; Bourget et al., 2010; Pouderoux et al., 2012). The prism's morphology in turn is driven by convergence rate, plate coupling, backstop strength, upper plate rheology, and lower plate topography and sedimentation history.
Paleoseismology can reveal the behavior of a fault system through multiple earthquake cycles (Atwater, 1987; McCalpin and Nelson, 1996; Atwater and Hemphill-Haley, 1997; Nelson et al., 2006; Goldfinger et al., 2008, 2012). Strong ground shaking from rupture of earthquakes has been inferred to trigger turbidity currents that potentially leave a very long record of past earthquakes in the form of turbidites (Dallimore et al., 2005; Goldfinger et al., 2003, 2008, 2012; Inouchi et al., 1996; Karlin and Seitz, 2007; Shiki et al., 2000; St-Onge et al., 2004). Turbidite paleoseismology uses combined evidence from sedimentology, tests of synchroneity, stratigraphic correlation, and analysis of non-earthquake triggers to develop a reliable earthquake record for submarine fault zones (Adams, 1990; Beattie and Dade, 1996; Goldfinger et al., 2012).

Turbidite paleoseismology has been largely successful in regions where an understanding of the flow systems and pathways (including secondary factors) and can be developed in order to maximize the potential for success through careful core site selection. While the tectonic interpretation of these deposits is not the principle focus of this paper, it is these interpretations (and correlation of deposits) which allow us to make our observations regarding the forcing factors along these two margins.

In the following sections we describe some site localities and turbidity current pathways along the Sumatra and Cascadia margins. Detailed turbidite correlations and seismogenic trigger rationale in Cascadia are found elsewhere (Goldfinger et al., 2012) and we discuss correlations and seismogenic rationale for Sumatra in this paper. These correlations are used here to provide a framework for discussion of architectural 


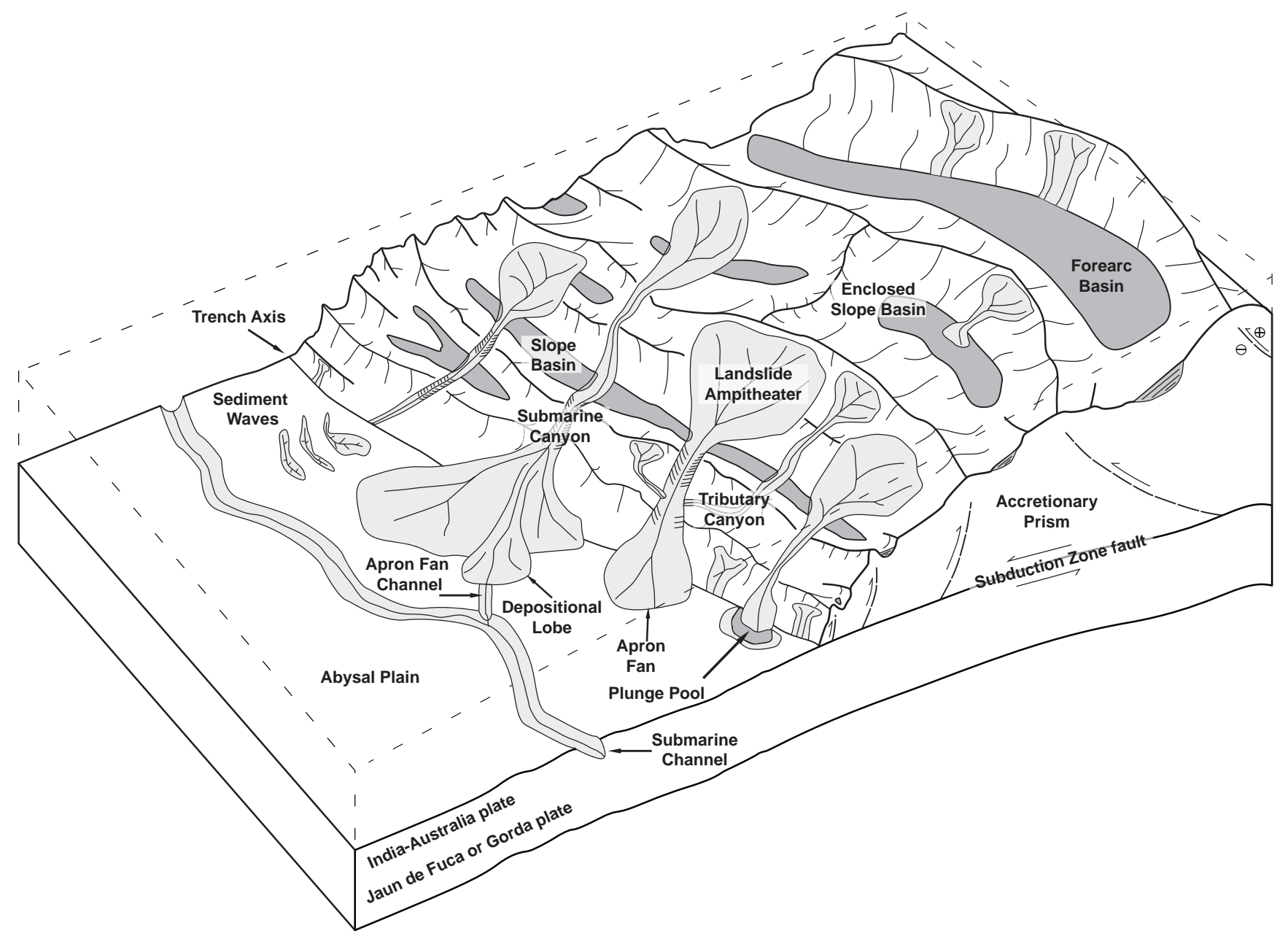

Fig. 1. Schematic illustration of geomorphic elements of subduction zone trench and slope sedimentary settings. Submarine channels, submarine canyons, dune fields and sediment waves, abyssal plain, trench axis, plunge pool, apron fans, and apron fan channels are labeled here and described in the text.

controls on turbidite sedimentation in marginal slope basin and trench settings of the Sumatra and Cascadia margins.

\subsection{Physical geography}

The sedimentary systems of the continental slope and abyssal plain offshore Sumatra and Cascadia are controlled largely by the tectonics of the accretionary prism and the glacial history of the regional and local sources of terrestrial sediment. There exists a wide range in sedimentary settings along both of the margins off Sumatra and Cascadia (Fig. 1).

The continental slope is formed by the accretionary prism of the subduction zone and many of these geographical features are controlled by the geometry of the prism (Wang and Davis, 1996; Wang and Hu, 2006). The intersection of the slope with the abyssal plain may be close to the trench axis (Sumatra), or may be the intersection of the frontal fault limb or megathrust with a filled trench (Cascadia). Submarine canyons cross the slope and may headwardly migrate through growing anticlinal folds, into slope basins and branch into tributary canyons. Submarine channel systems are meandering channels that form in the sediments of the abyssal plain and may follow the trench axis (Carter, 1988). In Sumatra, there is no active channel system resolvable in the axis. In Cascadia, the filled trench allows channels to trend away from the slope, following trends defined by Pleistocene fan systems and the age of the subducting Juan de Fuca plate. Channels emanate from submarine canyons and submarine landslide complexes at the base of the slope (Carter, 1988). Dune fields and sediment waves are multibeam-resolvable landforms that have bedforms in the shape of transverse dunes (Nelson et al., 2000). A plunge pool forms in the trench where sediment flows from the slope scour the area at the base of the slope (probably due to the steepness of the slope), forming a recessed pool (Nelson et al., 2000). Apron fans form at the base of the slope and may or may not have apron fan channels incised into their surface (Nelson et al., 2000). In the following sections, we will describe the specific landforms found in Sumatra and Cascadia, their interactions, and the relations to their hosted turbidite stratigraphy. 


\subsection{Sumatra margin}

The India-Australia plate subducts to the northeast at 38 to $57 \mathrm{~mm} \mathrm{yr}^{-1}$ beneath the Sunda plate to form the SumatraAndaman subduction zone (SASZ) in the northeast Indian Ocean (Subarya et al., 2006; Fig. 2). Bengal fan channels are ultimately sourced from the Himalayas and formed as a response to climate forcing, particularly during glacial periods (Curray and Moore, 1971; Curray et al., 2003; Weber et al., 2003). Bengal fan deposits thin to the south, as evidenced in ETOPO elevation data (Smith and Sandwell, 1997). Oceanic basement structures are generally buried north of $1^{\circ} \mathrm{N}$, and only partially buried south of that latitude (except along the outer rise and trenchward of the outer rise, where these structures are reactivated; the outer rise is a convex-up region west of the trench).

While active Himalayan sedimentation forms a fan in the northwestern Indian Ocean, turbidity current channels in the eastern Bengal fan are inactive since the late Quaternary as they no longer receive active sedimentation from northern sources (Moore et al., 1976; Weber et al., 2003). In the margin offshore northern Sumatra there is but a single relict turbidity current channel (sourced from the north) and it is not located in the trench axis, but is positioned westward of the outer rise, causing it to drain westward towards the Ninetyeast ridge. This relict channel does not reflect the modern gradients in topography as the India-Australia plate flexes here in response to subduction. There are no large channel systems in the trench, other than short (with a mean length of $7 \mathrm{~km}$ ) apron fan channels associated with submarine canyons exiting the continental slope and localized submarine landslide amphitheaters. Many of these short channels are offset and deformed by bending moment normal faults, further restricting or altering turbidity current flow in these systems.

Continental margin morphology west of Sumatra is dominated by the upper plate structure of a Tertiary and Quaternary accretionary prism with structural highs and forearc slope basins. Uplifted Tertiary-Quaternary Bengal and Nicobar fan sediments form the core of the duplexed accretionary prism offshore Sumatra, which acts as a local backstop (Fisher et al., 2007; Kopp et al., 2008; Singh et al., 2010; Krabbenhoeft et al., 2010). Topography here is controlled largely by the blocks of sediment up to $4 \mathrm{~km}$ thick (Bandopadhyay and Bandopadhyay, 1999; Fisher et al., 2007) uplifted from the India-Australia plate (likely by duplexing of the accretionary complex) to form the upper part of the accretionary prism and marginal plateau (Fisher et al., 2007). Between these blocks and fault anticlines are the piggyback slope basins that archive sediment in which we collected our cores (Fisher et al., 2007; Mosher et al., 2008; Gulick et al., 2011). Slope basins in the Sumatra system are formed atop this fold and thrust belt with submarine canyon systems linking some basins as they cut normal to the trench. Many basins do not drain to the trench and have an expanded Holocene section. Canyon systems tend to be short and drainage catchments relatively small possibly because there are no pathways through the accretionary complex to the forearc basin or continental shelf. The outer forearc is sedimentologically isolated from northern Sumatra by the Aceh, Simeulue, Nias, Pini, Siberut, and Bengkulu Neogene forearc basins (Sieh and Natawidjaja, 2000; Susilohadi et al., 2005). Sediment input from the offshore islands of Simeulue, Nias, and Siberut is possible for some basins in the central and southern Sumatra margin. Similarly the trench provides sedimentological isolation between sites due to the lack of large channel systems. In addition, core sites in the trench are isolated to sedimentologic sources further north along the SASZ. The trench is likely blocked from sedimentary input from northern sources by the subducting Ninetyeast ridge and a large landslide at $14^{\circ} \mathrm{N}$ (Moore et al., 1976).

The trench axis deepens from $4.5 \mathrm{~km}$ to $6.5 \mathrm{~km}$, from north to south, and is filled with sediment four km thick in the north (Gulick et al., 2011), all deeper than the carbonate compensation depth (CCD). Trench fill sediments are sourced from the Bengal and Nicobar fans and partially bury lower plate bending moment normal faults and fracture zones that trend across the trench. Along the central southern margin, sediments overlying the oceanic crust are thin to less than one $\mathrm{km}$. The trench axis morphology is therefore controlled by transverse structures from $2.25^{\circ} \mathrm{S}$ southward and the morphology in turn controls turbidite flow within the trench. Where larger lower plate structures, such as the Investigator fracture zone and the fossil Wharton ridge, cross the trench in a northeasterly direction, they block sediment flow southward down the trench axis. The result of these blockages is compartmented sediment basins in the trench axis. A secondary effect is that sediment sources in the trench compartments are restricted to sources of input from adjacent specific slope segments. It is notable that these lower plate structures that compartmentalize sediment deposition also align with many historic earthquake rupture limits (Newcomb and McCann, 1987; Ortiz and Bilham, 2003; Sieh, 2006; Briggs et al., 2006; Natawidjaja et al., 2004; Chlieh et al., 2007; Meltzner et al., 2010, 2012).

\subsection{Cascadia margin}

The Juan de Fuca and Gorda plates subduct to the northeast at 36 to $50 \mathrm{~mm} \mathrm{yr}^{-1}$ beneath the North America plate (Fig. 3) to form the Cascadia subduction zone (CSZ) in the northeast Pacific (McCaffrey et al., 2007). Sediment thicknesses on the lower plates decrease from $4 \mathrm{~km}$ to $<1 \mathrm{~km}$, north to south. Sediment thickness may play a role in seismogenic potential and segmentation of the margin due to unmasking of basement structures in southern Cascadia (Goldfinger et al., 2012), as it may in Sumatra, where sediment thickness similarly decreases southward. The N-S gradient in incoming sediment thickness results in a smooth plate interface along the northern margin and a relatively rough one in the south, where the subducting Blanco fracture zone and two 


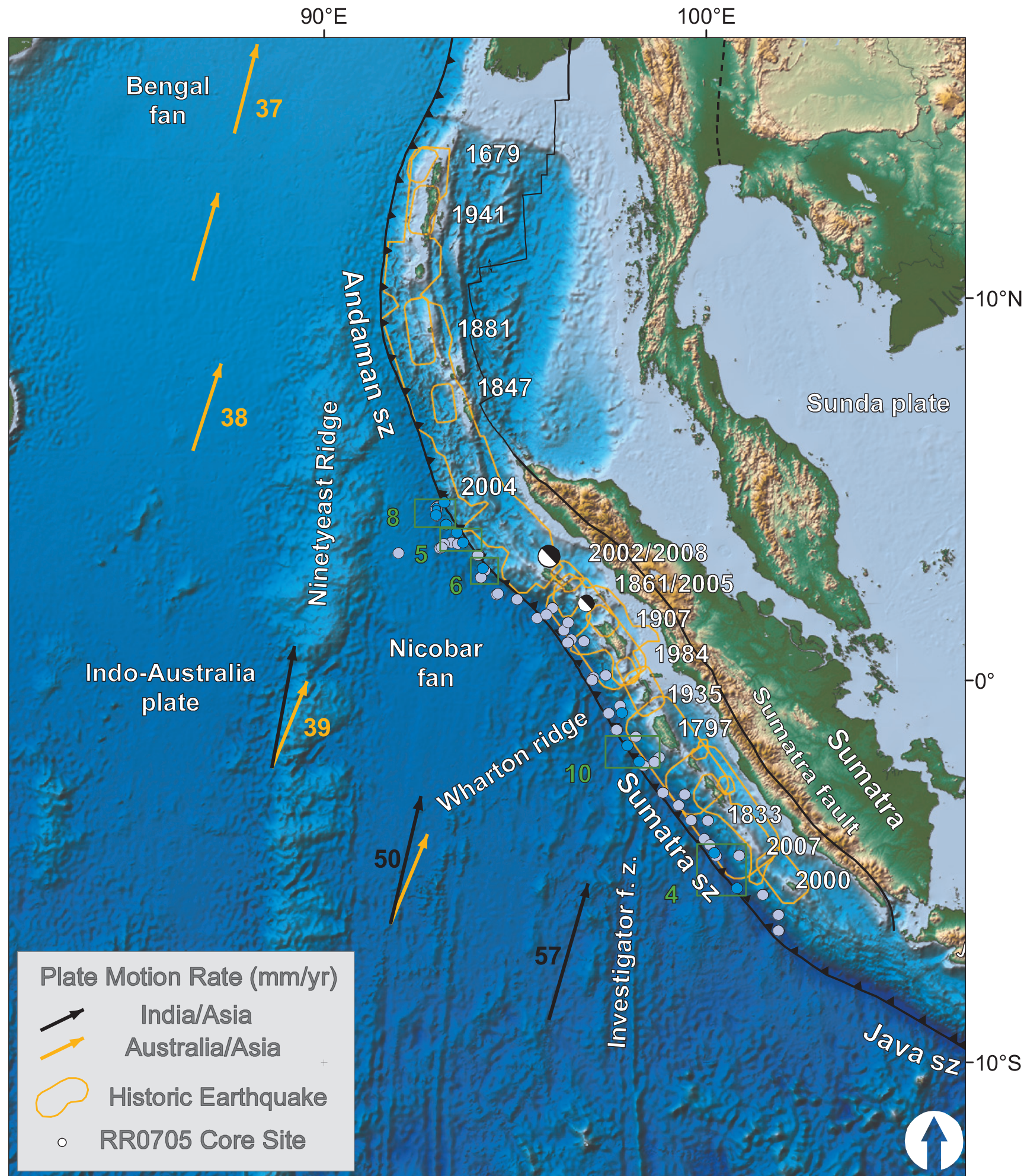

Fig. 2. Sumatra core location and plate setting map. India-Australia plate subducts northeastwardly beneath the Sunda plate (part of Eurasia) at modern rates (GPS velocities are based on regional modeling of Bock et al., 2003 as plotted in Subarya et al., 2006). Historic earthquake ruptures (Bilham, 2005; Malik et al., 2011) are plotted in orange. Bengal and Nicobar fans cover structures of the India-Australia plate in the northern part of the map. RR0705 cores are plotted as light blue and cores discussed in this paper are darker blue. General location for Figs. 1, 5, 6, 8, and 10 are designated by green rectangles. SRTM bathymetry and topography is in shaded relief and colored vs. depth/elevation (Smith and Sandwell, 1997). 


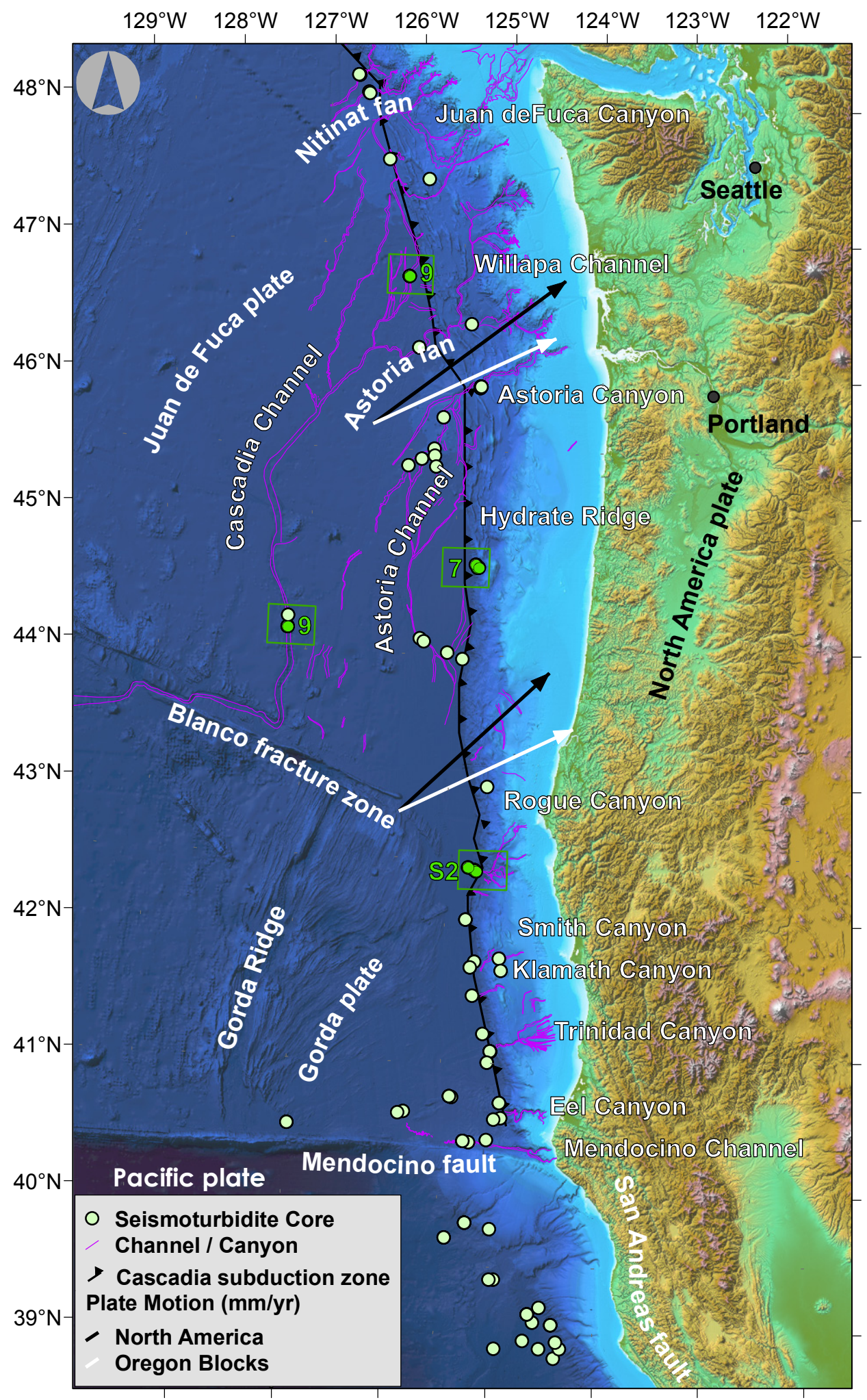

Fig. 3. Cascadia margin turbidite canyon, channel, and 1999, 2002, and 2009 core location map. Core sites are displayed as green circles and cores discussed in this paper are darker green. Bathymetric grid constructed from multibeam data collected in 1999, 2002, and 2009, Gorda plate swath bathymetry collected in 1997 (Dziak et al., 2001), and archive data available from NGDC. Bathymetry and topography in regions outside these higher resolution data sets are from the SRTM global data set (Smith and Sandwell, 1997). General location for Figs. 7, 9, and S2 are designated by green rectangles. Multibeam bathymetry data collected recently was compiled by Chris Romsos at Oregon State University (personal communication, 2012) 
pseudofaults are exposed (Chaytor et al., 2004; Goldfinger et al., 2012). Shorter rupture segments along the southern margin are attributed to this unmasking of basement structure in the south (Goldfinger et al., 2012). CSZ fault coupling in the submarine forearc is evidenced by deformation along accretionary prism faults as motion is transferred from lower plate sinistral faults (Goldfinger et al., 1997). Along with vergence of accretionary prism thrust faults (Goldfinger et al., 1996; Johnson et al., 2005), wedge taper and structural strike in the prism are likely controlled by basal shear stress on the CSZ fault (Goldfinger et al., 1992, 1996, 1997). These all contribute to the variability of plate coupling on the megathrust along both margins.

The accretionary prism here is composed of Tertiary to Quaternary turbidites and hemipelagic mud (Westbrook et al., 1994; Johnson et al., 2005). Basins in the CSZ slope are piggyback basins formed between the limbs of folds in the accretionary prism. These slope basins are commonly isolated, but are sometimes connected to other basins by relict channel systems, and are occasionally intersected by and connected to slope-perpendicular canyon systems. Several slope basins, notably Hydrate Ridge Basin West (HRBW), are completely isolated from terrestrial or shallow water sediment sources (Goldfinger et al., 2012). As in Sumatra, such isolated slope basins collect local sedimentation only from submarine landslides derived from the local slopes that define the basins.

The continental slope of the Cascadia margin is traversed by numerous submarine canyons that deliver an abundant sediment volume to the filled trench from the high-rainfall coastal region and continental interior (Fig. 3). The Columbia River, one of the largest rivers in North America, has delivered $\sim 20$ million metric tons of sediment per year mostly to the Washington shelf during the late Holocene (Sternberg, 1986; Wolf et al., 1999). During Pleistocene lowstands, when much of the Columbia River drainage basin was glaciated, a greater sediment load was delivered directly to the Cascadia Basin floor turbidite systems (Underwood, 2005). During that time, the broad Astoria and Nitinat Fans were constructed along the northern margin, and filled the subduction-zone trench (Nelson et al., 1968; Nelson et al., 1987; Normark and Reid, 2003; Goldfinger et al., 1997). During the Holocene high stand, sediment from Cascadia rivers was deposited mostly on the shelf and in nearly full shelf basins and upper canyons (Goldfinger et al., 1992; McNeill et al., 2000), $11 \%$ of the load estimated to be delivered to canyon heads offshore Washington and northern Oregon (Sternberg, 1986; Wolf et al., 1999).

A wide variety of modern turbidite systems are found within Cascadia Basin (Nelson et al., 2009, 2001). Base-ofslope sand-rich apron fans, such as Rogue Apron, are defined as small-scale $(<10 \mathrm{~km})$, wedge-shaped turbidite systems abutting the base of slope (Nelson et al., 2000, 2009, 2011). They do not have significant channel development detectable in seismic profiles, side-scan mosaics, or swath-bathymetry at the resolution of presently available data (Wolf et al., 1999; Goldfinger et al., 2012; this study). Submarine fans, such as Astoria Fan, are turbidite systems with significant channel development that funnel sediment into outer-fan depositional lobes. Another turbidite system type commonly found in active-margin settings is the extensive, tectonicallycontrolled, deep-sea channel system. Deep-sea channel systems, such as Cascadia Channel, are fed by multiple tributary canyons, extend for hundreds to thousands of kilometers across basin floors and eventually connect with abyssalplain fans (Carter, 1988; Nelson et al., 2000). Large-scale sediment-wave or dune fields and plunge pools associated with high gradient canyon mouths and proximal channels, such as those of the Trinidad and Eel systems, also have been observed in swath-bathymetric and sidescan mosaics of basin floors (Nelson et al., 2009, 2000; EEZ-Scan 84 Scientific Staff, 1986; Goldfinger et al., 2012). In a tectonically active setting like the Cascadia margin, folding, faulting, and extensive sediment failures can disrupt canyon and channel pathways of turbidite systems.

\subsection{Seismoturbidites}

Adams (1990), Goldfinger et al. (2003), and Shanmugam (2008) suggest nine plausible triggering mechanisms for turbidity currents: (1) storm wave loads, (2) earthquake ruptures, (3) tsunami wave loads (local or distant), (4) sediment loads, (5) hyperpycnal flows, (6) volcanic explosions, (7) submarine landslides, (8) cyclones, and (9) bolide impacts. Other mechanisms may reduce slope stability (tectonic oversteepening, depositional oversteepening, sea-level lowering, salt movement, glacial loading, biologic erosion), but are likely random and not regional nor synchronous (Inouchi et al., 1996; Goldfinger et al., 2007). Discriminating between these mechanisms is central to using turbidites for paleoseismology. While subduction zones generate sufficient seismicity to seismically strengthen sediments so these settings are more resistant to other triggering mechanisms (Biscontin and Pestana, 2006; Nelson et al., 2011), we will first discuss relevant alternative triggers.

Considering alternative triggers, hyperpycnal storm flow related deposits (hyperpycnites) may have a finer sediment base that initially coarsens upwards (during waxing flow), then fines upwards (as the flow wanes; Mulder et al., 2003) though this sequence may also not be represented in the deposit. With wave triggers, the landslide source area would be much shallower than the source areas in the region of this study. Tsunami waves and storm waves can cause liquefaction and erosion at upper canyon and shelf depths, but source areas for our cores are not at these shallow depths. Tsunami wash-back sediments have been found in Sumatra (Sugawara et al., 2007) and elsewhere (Bondevik et al., 1997; Fujiwara et al., 2000; van den Bergh et al., 2003; Noda et al., 2007; Abrantes et al., 2008), but these are also at much shallower depths than sampled in this study. Typically, wave 
related triggering causes upper canyon transport, but not necessarily ignition of a turbidity current that might reach deep water (Goldfinger et al., 2012). Gas Hydrate destabilization would leave behind highly localized deposits. Bolide impacts may also lead to turbidites, but their recurrence is too rare to explain the chronostratigraphy in the cores from this study. These and other mechanisms are discussed in detail for Cascadia in Goldfinger et al. (2012). Thus sedimentologic discriminators between these mechanisms are possible, as are frequency comparisons, but these are hardly universal. The primary basis for attributing a seismogenic trigger to the turbidite record is testing for regional and synchronous deposition, combined with comparison to historic and other paleoseismic data (Goldfinger et al., 2007, 2008, 2012).

Earthquakes are well known as subaerial landslide triggers, with a triggering minimum earthquake magnitude of $\sim M_{\mathrm{w}}=5$ (Keeper, 1984), and landslide density found to be greater in areas of stronger ground acceleration (Meunier et al., 2007; Strasser et al., 2006). Earthquakes are also one of the dominant submarine landslide triggers (Hampton et al., 1996; Masson et al., 2006; Goldfinger et al., 2003, 2008, 2012), with most historic examples attributed to ground accelerations from earthquakes (Mosher et al., 2010; Shirai et al., 2010; Mosher and Piper, 2007; St-Onge et al., 2004, 2011). Minimum magnitudes for recording seismoturbidites are possibly above $M_{\mathrm{w}}=7.1$ (Goldfinger et al., 2003) or $M_{\mathrm{w}}=7.4$ (Nakajima and Kanai, 2000) in subduction zone settings, though smaller magnitudes $\left(M_{\mathrm{W}}=5.2\right)$ have been observed (Lorenzoni et al., 2012a) and are supported by studies of slope stability and minimum accelerations required for failure (e.g. Goldfinger et al., 2013).

We test the plausibility of a seismogenic trigger in Sumatra by (1) using tests for synchronous triggering of sedimentologically isolated turbidite systems and (2) using secondary constraints that consider sedimentologic characteristics of the turbidites. When turbidites can be correlated between sites separated by a large distance or between sites isolated from land sources and from each other, synchronous triggering can be inferred and most other triggering mechanisms can be eliminated (Goldfinger et al., 2003, 2008, 2012; Shiki et al., 2000; Gorsline et al., 2000; Nakajima, 2000; Rajendran et al., 2008; Shiki et al., 2000).

Attributing a seismogenic trigger to turbidites generally requires spatial and temporal correlation of individual turbidites (Shiki et al., 2000; Gorsline et al., 2000; Nakajima, 2000; Goldfinger et al., 2003, 2008, 2012; Rajendran et al., 2008). Kneller and McCaffrey (2003) and Baas et al. (2005) pose that the vertical structure (Sanders, 1965) is predicted when there are longitudinal (along the flow path) changes in sediment flux within turbidity currents. Source-time functions and rupture geometry of earthquakes may provide this spatial and temporal control on sediment input into these turbidity current systems. The turbidite structure (stratification) left behind by these flows thus possibly records an approximation of the seismic energy density at the landslide source area (Goldfinger, 2011; Goldfinger et al., 2012, 2013).

Mass wasting along continental margin slope settings has a large range in genetics, from block falls to nepheloid raveling (Nelson et al., 2000; Lorenzoni et al., 2012b). However, little is known about the initial slope failures that lead to turbidity currents along the CSZ and SASZ margins. These turbidity currents may begin as a wide range of mass wasting types, but eventually transform into turbulence driven buoyant sediment rich flows (Nelson et al., 2011). These turbidity currents can travel 100s to 1000s of kilometers if channels and basins extend that distance (Nelson et al., 1968, 2011; Goldfinger et al., 2003). When turbidity currents are localized in slope basins, they may only travel much shorter distances or may escape the slope basin margins by flowing uphill, and may be reflected within these slope basins (Kneller and McCaffrey, 1995; Bourget et al., 2011; Pouderoux et al., 2012). When currents travel in restricted settings (slope basins or other settings with no channels), deposits left behind are controlled largely by source proximity (Nelson et al., 1986), but may also be subject to bypassing and hydraulic jumps that complicate the recording at any given site (Goldfinger et al., 2012).

Coring for seismoturbidites requires an evaluation of these competing factors so that the coring sites can be optimized to reduce complicating factors while enhancing the likelihood of recording earthquakes. Here we review coring sites from Sumatra and Cascadia as they relate to these competing turbidite structure forcing factors. We also discuss the correlation of these deposits for stratigraphy offshore Sumatra.

\section{Data and methods}

\subsection{Site survey}

We mapped the seafloor and shallow subsurface in order to select coring sites in optimal locations for collecting records of turbidity current deposition. For cruises on the R/V Thomas G. Thompson (CSZ: 2009, TN0909 cores), R/V Roger Revelle (CSZ: 2002, RR0702 cores; SASZ: 2007, RR0705 cores), and R/V Melville (CSZ 1999, M9907 cores) where cores were collected for paleoseismic studies, multibeam mapping was essential to evaluate the physiographic setting for the relevant sedimentary systems. Multibeam sonar mapping of the seafloor is collected and edited on board so that coring sites can be chosen in real-time (e.g. RR0705 Superquakes07 Cruise Report http://www.activetectonics.coas.oregonstate. edu/sumatra/report/index.html). Prior to the cruises, existing bathymetric data are compiled. Sumatra bathymetry was collected by Japanese (R/V Natsushima: Japan Agency for Marine Earth-Science and Technology, Jamstec), United Kingdom (HMS Scott: UK Royal Navy and Southampton Oceanography Centre, NOCS), French (R/V Marion 
Table 1. Cores and their depositional settings.

\begin{tabular}{|c|c|c|c|c|c|c|}
\hline Margin & $\begin{array}{l}\text { Core } \\
\text { Name }\end{array}$ & $\begin{array}{l}\text { Core } \\
\text { Setting }\end{array}$ & $\begin{array}{l}\text { Site } \\
\text { Geomorphology }\end{array}$ & $\begin{array}{r}\text { Depth } \\
(\mathrm{m})\end{array}$ & $\begin{array}{r}\text { Latitude } \\
\text { Deg. DM }\end{array}$ & $\begin{array}{r}\text { Longitude } \\
\text { Deg. DM }\end{array}$ \\
\hline Sumatra & RR0705-108PC & Slope Basin & center of wide unconfined valley & 2959 & $4^{\circ} 39.58^{\prime} \mathrm{N}$ & $93^{\circ} 08.6^{\prime} \mathrm{E}$ \\
\hline Sumatra & RR0705-104PC & Slope Basin & base of slope & 3477 & $3^{\circ} 52.3^{\prime} \mathrm{N}$ & $93^{\circ} 28.5^{\prime} \mathrm{E}$ \\
\hline Sumatra & RR0705-103PC & Slope Basin & center of wide unconfined valley & 3077 & $3^{\circ} 36.3^{\prime} \mathrm{N}$ & $93^{\circ} 37.9^{\prime} \mathrm{E}$ \\
\hline Sumatra & RR0705-96PC & Slope Basin & undrained basin & 3399 & $2^{\circ} 56.0^{\prime} \mathrm{N}$ & $94^{\circ} 08.4^{\prime} \mathrm{E}$ \\
\hline Sumatra & RR0705-79PC & Slope Basin & undrained basin & 3833 & $0^{\circ} 50.8^{\prime} \mathrm{S}$ & $97^{\circ} 47.6^{\prime} \mathrm{E}$ \\
\hline Sumatra & RR0705-03PC & Trench & trench axis & 4443 & $4^{\circ} 32.2^{\prime} \mathrm{N}$ & $92^{\circ} 56.0^{\prime} \mathrm{E}$ \\
\hline Sumatra & RR0705-05PC & Trench & trench axis & 4480 & $4^{\circ} 28.8^{\prime} \mathrm{N}$ & $92^{\circ} 55.6^{\prime} \mathrm{E}$ \\
\hline Sumatra & RR0705-107PC & Trench & above trench floor & 4518 & $4^{\circ} 19.6^{\prime} \mathrm{N}$ & $92^{\circ} 55.1^{\prime} \mathrm{E}$ \\
\hline Sumatra & RR0705-105PC & Trench & near trench axis & 4486 & $4^{\circ} 04.7^{\prime} \mathrm{N}$ & $93^{\circ} 10.9^{\prime} \mathrm{E}$ \\
\hline Sumatra & RR0705-38GC & Trench & trench axis & 5524 & $1^{\circ} 41.9^{\prime} \mathrm{S}$ & $97^{\circ} 56.3^{\prime} \mathrm{E}$ \\
\hline Sumatra & RR0705-37GC & Trench & above trench floor & 5497 & $1^{\circ} 42.4^{\prime} \mathrm{S}$ & $97^{\circ} 55.3^{\prime} \mathrm{E}$ \\
\hline Sumatra & RR0705-41GC & Trench & trench axis & 5620 & $2^{\circ} 07.7^{\prime} \mathrm{S}$ & $98^{\circ} 14.6^{\prime} \mathrm{E}$ \\
\hline Sumatra & RR0705-40GC & Trench & above trench floor & 5530 & $2^{\circ} 08.1^{\prime} \mathrm{S}$ & $98^{\circ} 13.3^{\prime} \mathrm{E}$ \\
\hline Sumatra & RR0705-55PC & Trench & near trench axis & 6046 & $4^{\circ} 31.2^{\prime} \mathrm{S}$ & $100^{\circ} 12.8^{\prime} \mathrm{E}$ \\
\hline Sumatra & RR0705-57PC & Trench & near trench axis & 6069 & $5^{\circ} 26.4^{\prime} \mathrm{S}$ & $100^{\circ} 47.9^{\prime} \mathrm{E}$ \\
\hline Cascadia & RR0207-01KC & Slope Basin & undrained basin, Hydrate Ridge West Basin & 2110 & $44^{\circ} 40.0^{\prime} \mathrm{N}$ & $125^{\circ} 17.1^{\prime} \mathrm{W}$ \\
\hline Cascadia & RR0207-56PC & Slope Basin & undrained basin, Hydrate Ridge West Basin & 2250 & $44^{\circ} 38.6^{\prime} \mathrm{N}$ & $125^{\circ} 15.8^{\prime} \mathrm{W}$ \\
\hline Cascadia & RR0207-02PC & Slope Basin & undrained basin, Hydrate Ridge West Basin & 2311 & $44^{\circ} 38.7^{\prime} \mathrm{N}$ & $125^{\circ} 15.0^{\prime} \mathrm{W}$ \\
\hline Cascadia & M9907-12PC & Trench & Cascadia Channel & 2658 & $46^{\circ} 46.4^{\prime} \mathrm{N}$ & $126^{\circ} 04.9^{\prime} \mathrm{W}$ \\
\hline Cascadia & M9907-23PC & Trench & Cascadia Channel & 3211 & $44^{\circ} 09.6^{\prime} \mathrm{N}$ & $127^{\circ} 11.5^{\prime} \mathrm{W}$ \\
\hline Cascadia & TN0909-01JC & Trench & Cascadia Channel & 3089 & $42^{\circ} 26.3^{\prime} \mathrm{N}$ & $125^{\circ} 16.6^{\prime} \mathrm{W}$ \\
\hline Cascadia & M9907-30PC & Trench & base of slope & 3112 & $42^{\circ} 25.2^{\prime} \mathrm{N}$ & $125^{\circ} 13.1^{\prime} \mathrm{W}$ \\
\hline Cascadia & M9907-31PC & Trench & base of slope & 3107 & $42^{\circ} 24.6^{\prime} \mathrm{N}$ & $125^{\circ} 12.0^{\prime} \mathrm{W}$ \\
\hline
\end{tabular}

Dufresne: Ifremer), and German (R/V Sonne: Federal Institute for Geosciences and Natural Resources, BGR) ships and shared utilizing a cooperative agreement with these international institutions and the Indonesian Government (Agency for the Assessment and Application of Technology, BPPT), without which, the coring study would not have been possible (Henstock et al., 2006; Ladage et al., 2006). Prior to the 1999 and 2002 cruises, existing Cascadia bathymetry was compiled by Dziak et al. (2001) and Goldfinger et al. (2003). These Cascadia compilations included older swath bathymetry (including SeaBeam 2000, SeaBeam Classic, and Hydrosweep), as well as multibeam bathymetry. $3.5 \mathrm{kHz}$ Compressed High Intensity Radar Pulse (CHIRP) seismic profiles of the shallow sub-bottom is also an important data set to collect when locating core sites. These data reveal the continuity (or lack thereof) of repeated local turbidite sedimentation, local faulting, and mass wasting deposits, and may be useful in projecting the seismic record beyond the depth limits of coring campaigns.

\subsection{Coring and lithostratigraphic correlation}

Piston and gravity coring are the primary methods used to collect strata from the sea floor, supplemented with Kasten-, box-, and multi-cores (the latter two are used to sample the sediment-water interface and the upper-most units with minimal disturbance). Kasten cores are useful as they provide a larger volume of sediment from which volume restricted age samples $\left(\mathrm{CaCO}_{3}\right.$ foraminiferid tests) are collected. Cores are scanned for geophysical properties (multi sensor core logging (MCSL): gamma density, magnetic susceptibility, p-wave velocity, and resistivity) and then split lengthwise and described on lithostratigraphic data sheets. Following the cruise, cores are then scanned with Computed Tomographic X-ray techniques (CT scans). CT data also provide densostratigraphic information (down-core variation in density) when CT imagery is used for downcore line-scan analysis. Other post-cruise analytical methods that are used include laser diffraction particle size measurements, down-core $\mathrm{X}$ ray fluorescence (XRF), superconducting rock magnetometer measurements of remnant magnetization, high-resolution point magnetic susceptibility measurements, ${ }^{210} \mathrm{~Pb}$ and ${ }^{137} \mathrm{Cs}$ isotopic analyses, and accelerator mass spectrometry (AMS) radiocarbon age control. Core geophysical methods are further summarized in Document 1 in the Supplement.

Cores 55PC and 57PC are used to demonstrate the technique of flattening geophysical data between cores in order to examine potential correlatives (Fig. 4). All correlations done in this paper are made using this technique, where the vertical scale of one data set are scaled to match the vertical scale of the other core's data set, based on the upper and lower stratigraphic contacts of the sedimentary deposits (Thompson et al., 1975). MSCL data for core 57PC is "flattened" to the stratigraphic horizons in core 55PC on the left, and 55PC is 
A.

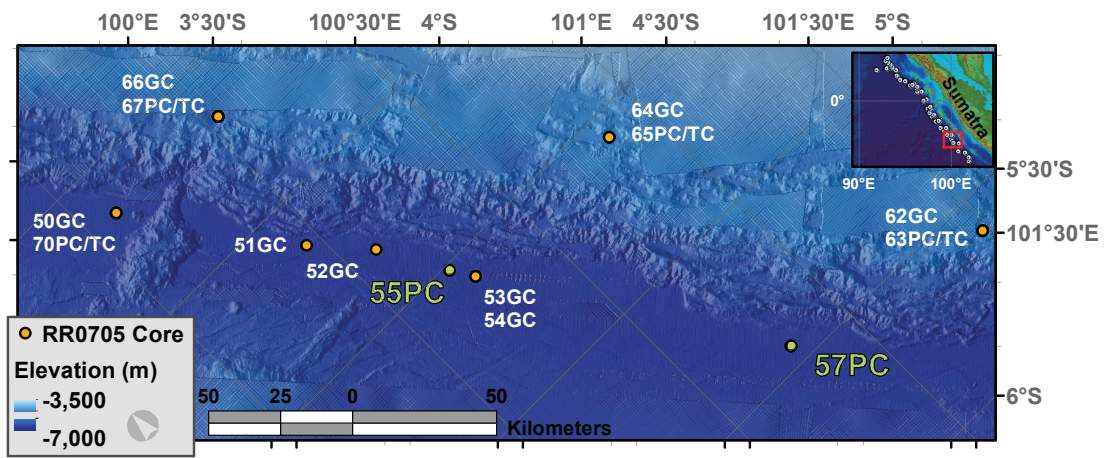

B.

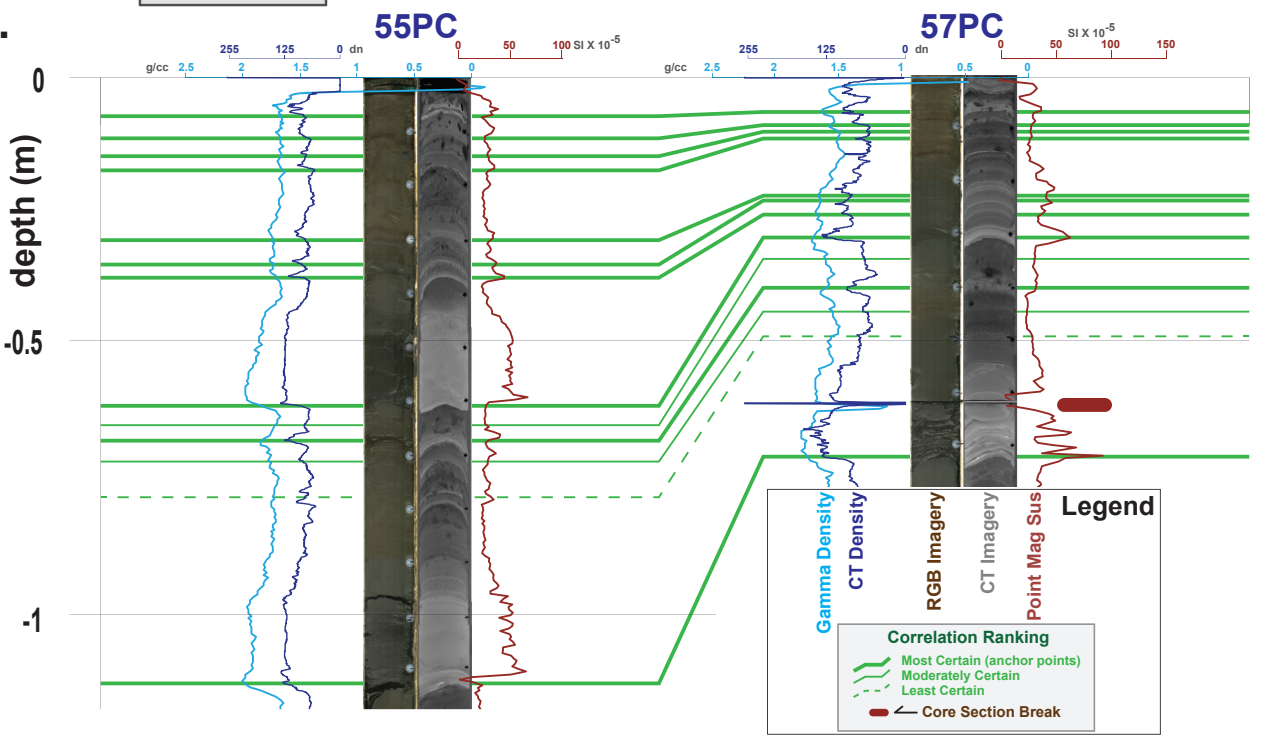

C.

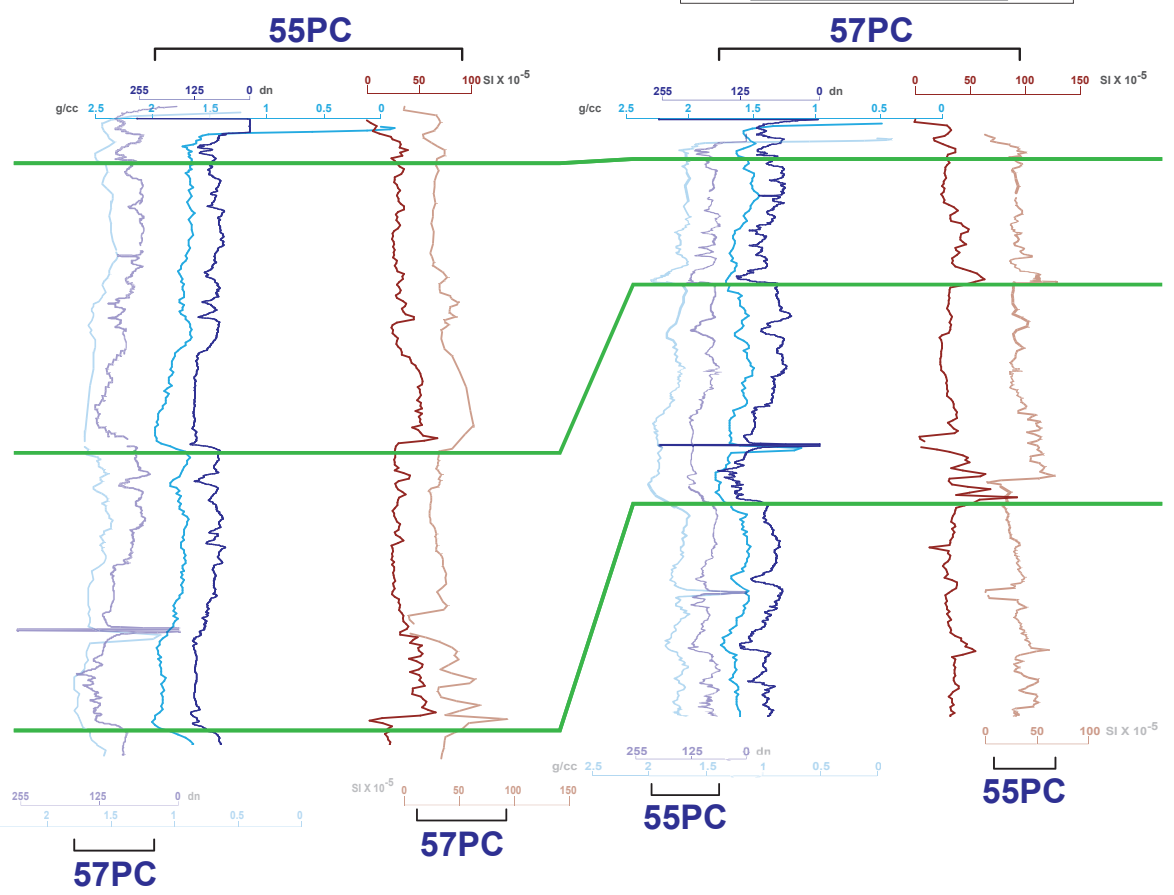

Fig. 4. Correlation of sedimentary units using standard stratigraphic correlation techniques between cores RR0705-55PC and RR0705-57PC. (A) Bathymetric map with cores plotted as brown dots and depth contours with $500 \mathrm{~m}$ spacing. Cores 55PC and $57 \mathrm{PC}$ are located in the trench approximately $120 \mathrm{~km}$ from each other. (B) Stratigraphic correlations between these cores using lithology, CT, and geophysical properties. Multi Sensor Core Log (MSCL) data are plotted beside RGB imagery and CT imagery that displays lower density material in darker grey and higher density material in lighter grey. Gamma density, CT density, point magnetic susceptibility, and loop magnetic susceptibility are plotted left to right as light blue, dark blue, dark red, and light red. The relative certainty of any individual correlation is ranked and designated by line symbology. (C) MSCL data for core 57PC is "flattened" to stratigraphic horizons in core 55PC on the left, and 55PC is flattened to 57PC on the right. The core data being flattened is partially transparent and plotted on the outside of the core data they are being flattened to (known as "ghost tracing"). The unflattened core data are scaled at the same vertical scale as in (B). 


\section{Sumatra Slope-Basin Cores}

A.

Proximal

Distal

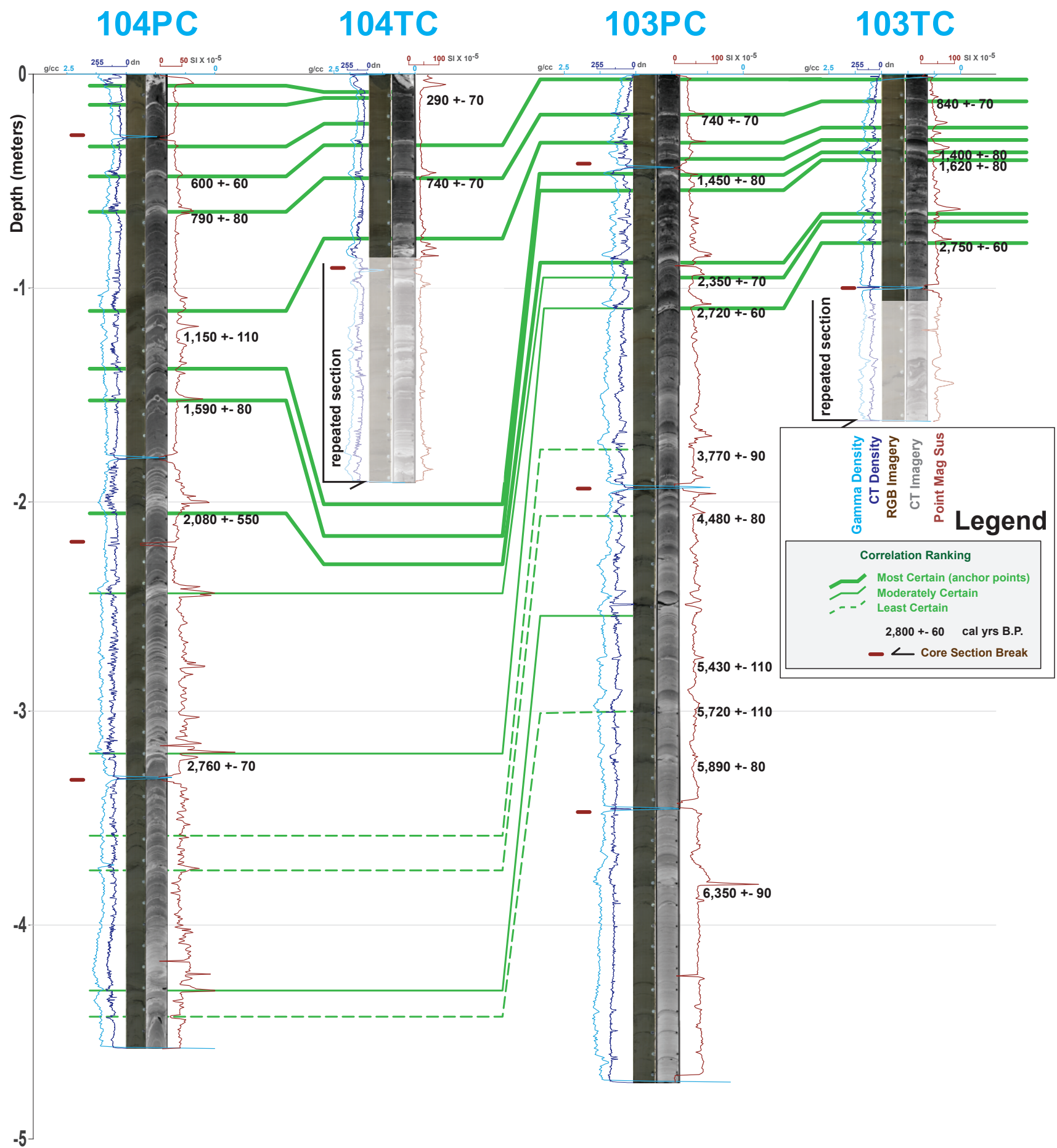

Fig. 5. Sumatra slope basin cores RR0705-104PC and RR0705-103PC. As in all figures and throughout this paper: PC, = Piston core; BC, Box core; KC, Kasten core; GC, Gravity core; $\mathrm{MC}=$ Multi core. (A) Stratigraphic correlations between these cores using lithology, CT, geophysical properties, and ${ }^{14} \mathrm{C}$ data. Multi Sensor Core Log (MSCL) data are plotted beside RGB imagery and CT imagery that displays lower density material in darker grey and higher density material in lighter grey. Gamma density, CT density, point magnetic susceptibility, and loop magnetic susceptibility are plotted left to right as light blue, dark blue, dark red, and light red. Radiocarbon ages are calibrated and reported with $95 \%$ error as is true for all ages in this paper (Table S1). "Repeated section" refers to strata that have been double cored. This happens when the trigger core barrel is inserted into the sea floor twice or more due to ship heave, thus sampling the same sediments twice or more (104TC has double repeated section). 
flattened to 57PC on the right. The core data being flattened is $50 \%$ transparent and plotted on the outside of the core data they are being flattened to. The unflattened core data are scaled at the same vertical scale as in B.

For basin cores, we selected cores from a variety of basin and trench settings (Table 1). Sumatra cores RR0705104PC/TC, RR0705-103PC/TC, and RR0705-96PC/TC are each in different basin settings: base of cliff, center of canyon, and center of closed basin, respectively (Figs. 2, 5, and 6). These cores are located in the region of the 2004 SASZ earthquake (Aceh Segment, Kopp et al., 2008) and span a trench-parallel distance of $350 \mathrm{~km}$. Cascadia cores RR0207-56PC/TC, RR0207-02PC/TC, and RR0207-01KC are all in the same basin: Hydrate Ridge Basin West and are within $4 \mathrm{~km}$ of each other (Fig. 7). The Hydrate Ridge cores are also spaced in relation to the landslide sources from proximal to distal.

For our selected trench cores, also in the Aceh Segment, Sumatra cores RR0705-03PC/TC, RR0705-05PC/TC, and RR0705-107PC/TC are at the northernmost extent of our cores along a $24 \mathrm{~km}$ transect (Fig. 8). Cascadia core M990712PC from the Juan de Fuca channel system is then compared with the Cascadia Channel core M9907-23PC, $350 \mathrm{~km}$ down channel (Fig. 9). We discuss two pairs of Sumatra base of slope apron cores RR0705-38GC, RR0705-37GC, RR0705-41GC, and RR0705-40GC; separated by $60 \mathrm{~km}$ in the Siberut Segment (Fig. 10, Kopp et al., 2008). Then we finally evaluate Cascadia cores TN0909-01JC, M9907-30PC, and M9907-31PC at the base of Rogue Canyon, spanning an $8 \mathrm{~km}$ transect (Fig. S2). Cruise prefixes for core names will be left out in some cases later in the paper.

\subsection{Geophysical logging and lithostratigraphic correlation}

Stratigraphic correlation using geophysical signatures representing vertical turbidite structure is a primary tool for testing individual deposits for their areal extent, a significant part of the criteria used to discriminate seismoturbidites from other possible types. Downcore geophysical properties are used as proxies for particle size, though this is specific to regional lithology and must be tested with detailed grain size measurements. We use laser diffraction particle size measurements (taken with a Beckman-Coulter LS 13-320 laser counter, Blott and Pye, 2006) to discuss our justification for this proxy in the results section. The form of the geophysical signature of each turbidite is referred to as its "fingerprint". Geophysical wiggle matching (fingerprinting: Goldfinger et al., 2007) of turbidites is based on the correlation of identifiable stratigraphic characteristics using MSCL data (Fukuma, 1998). This correlation technique has been used to correlate stratigraphic units since the 1960s (Prell et al., 1986; Lovlie and Van Veen, 1995). In detail these "fingerprints" represent the time history of deposition of the turbidite and have been shown to correlate between independent sites separated by large distances and depositional settings (Abdeldayem et al., 2004; Karlin et al., 2004; St-Onge et al., 2004; Hagstrum et al., 2004; Goldfinger et al., 2008, 2012). The detailed matching of records has been attributed to generation by the sourcetime function of the earthquake trigger (Goldfinger et al., 2012, 2013). The turbidite itself is commonly composed of single or multiple coarse fraction fining upward units termed "pulses". The rarity of a fine tail (Bouma Td and Te) or subsequent hemipelagic sediment between pulses indicates there is commonly little or no temporal separation between units. The lack of temporal separation of the pulses in Cascadia has been inferred to represent deposition over minutes to hours, and thus most likely represent sub-units of a single turbidite (Goldfinger et al., 2013).

\subsection{Age control}

Radiocarbon ages provide an important test to our correlations and there can be some exceptions (detailed methods are in Document 1 in the Supplement). Sumatra trench cores are deeper than the CCD, so they do not contain calcareous material sufficient for ${ }^{14} \mathrm{C}$ age control. For this reason, correlations between these and other cores do not have an age test for the fingerprint correlation. Radiocarbon discussion for the Cascadia cores is found in Goldfinger et al. (2012).

The laboratory radiocarbon ages are reported in years before present (BP, measured from 1950) with a two standard deviation lab error (Stuiver et al., 1998). ${ }^{14} \mathrm{C}$ ages are calibrated (Stuiver and Braziunes, 1993) and, for Sumatra ages, a marine reservoir Delta $R$ correction of $16 \pm 11 \mathrm{yr}$ is made using the INTCAL09 database (Reimer et al., 2009). Only two delta $R$ values are available for the Sumatra area, and while constraints are few on this correction, we here are correlating marine sites to other nearby marine sites, thus the local correlations are valid while absolute ages may contain additional uncertainty (see Goldfinger et al., 2012 for the reservoir correction information for the Cascadia cores). One additional correction we make to the calibrated age is the sediment gap and sample thickness correction (thickness of sediment between the turbidite and the sample and sample thickness, respectively). For individual ages, we propagate these uncertainties using RMS (root mean square) calculations using estimates of the uncertainties at each step. This calculation includes the lab uncertainties and results in the final reported $95 \%$ range for each radiocarbon age in calendar years before present (cal yr BP; Stuiver and Polach, 1977). No lab multipliers were applied to the data.

In order to evaluate the timing of the possible 2004 turbidite with radiometric techniques, we collected sediment samples below the turbidite at $1 \mathrm{~cm}$ spacing. ${ }^{210} \mathrm{~Pb}$ and ${ }^{137} \mathrm{Cs}$ isotopic analyses can provide information about the depositional history of the last $\sim 150 \mathrm{yr}$ (Noller, 2000). Samples were analyzed by Guillaume St. Onge at Institut des sciences de la mer de Rimouski. 

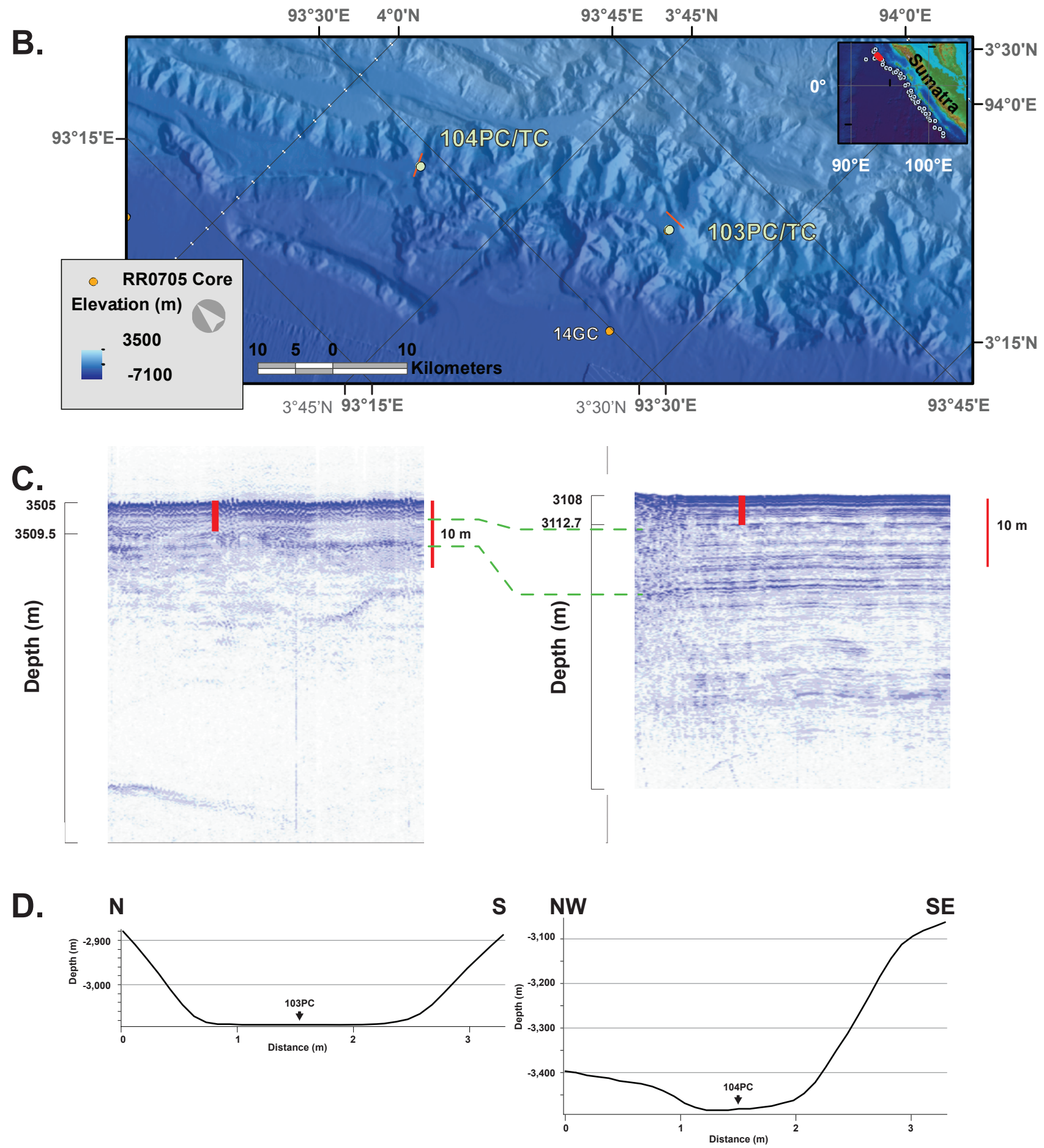

Fig. 5. (B) Core sites are plotted as orange circles on compiled bathymetry data set described in the text (Ladage et al., 2006). Inset map shows location of large map in red (northern margin) and cores in main map are orange dots. (C) $3.5 \mathrm{kHz}$ CHIRP seismic data collected at core sites are processed in SioSeis and plotted in SeiSee (seismic envelope). Core locations are designated by a red line scaled to core length. The x-axis for the seismic plots is not distance, but shot number. These seismic data were collected while the ship was staying on position during coring. (D) Elevation is plotted versus distance across the basins for cores 104 and 103 . Profile locations are plotted as orange lines in (B). 


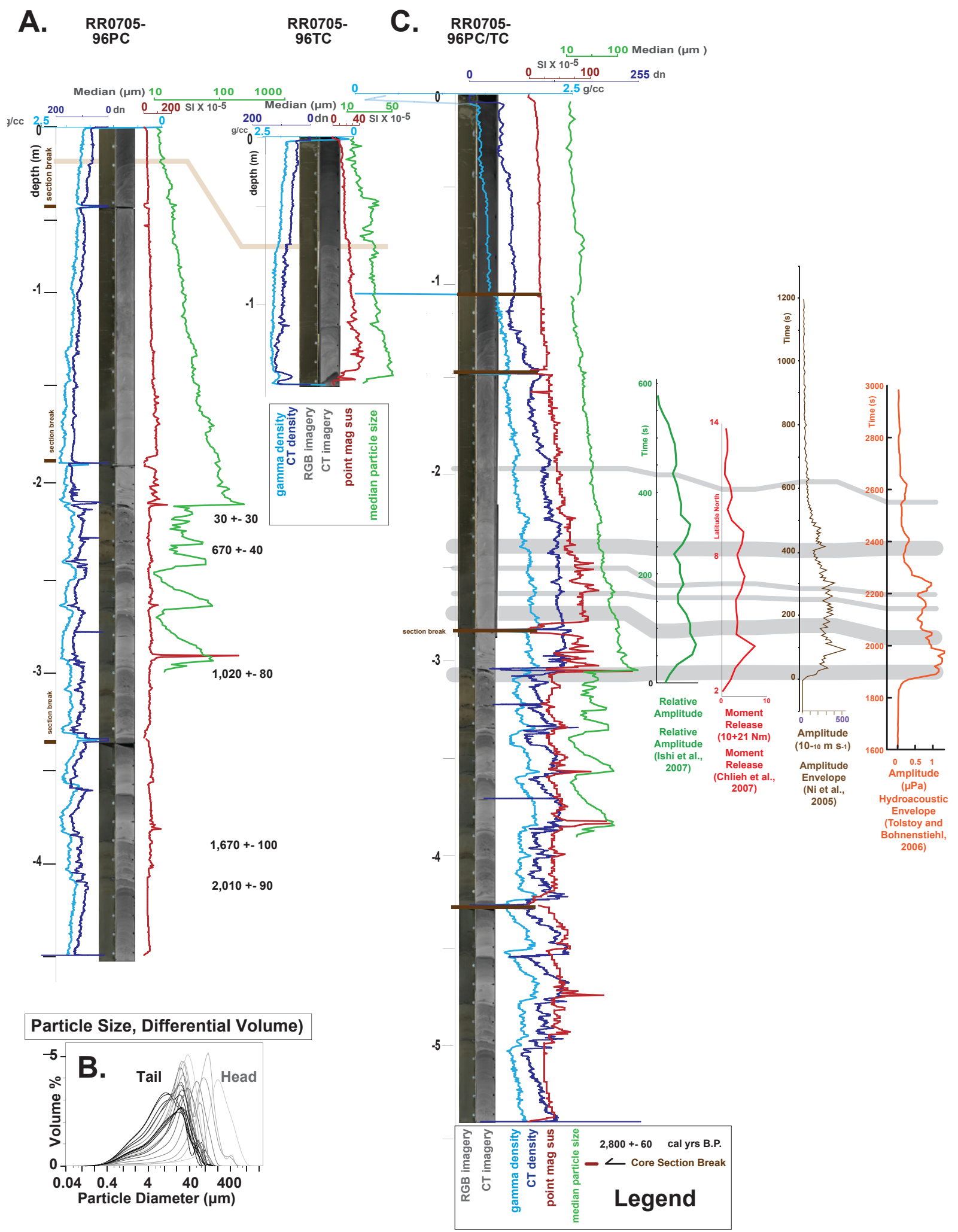

Fig. 6. Sumatra slope basin cores with an expanded Holocene section (Fig. 3). (A) RR0705-96PC is plotted with the same configuration as Fig. 2. Median grain size data are plotted in green with $1 \mathrm{~cm}$ spacing. (B) Particle size distribution data from sample locations at $10 \mathrm{~cm}$ spacing found in (A) are plotted by volume (\%) vs. particle size ( $\mu \mathrm{m}$, log scale) with lines generally designating samples' depth where the lighter lines have a larger mean size and are generally lower in section. Differential volume displays the percent volume of each particle size. (C) Core 96TC is scaled to 96PC and graphically spliced above 96PC to generate this composite core 96PC/TC. Moment release (vs. latitude) in red (Chlieh et al., 2007) and relative amplitude (vs. time) in green (Ishii et al., 2007), brown (Ni et al., 2005), and orange (Tolstoy and Bohnenstiehl, 2006) are scaled to match peaks in the loop ms data from composite core RR0705-96PC/TC. Thick grey tie lines correlate the beginning of seismic peaks with each other and with base of peaks in the core geophysical data. Thin grey lines show secondary correlations (lower seismic energy and lower amplitude core geophysical data). 


\section{Core Site Map}

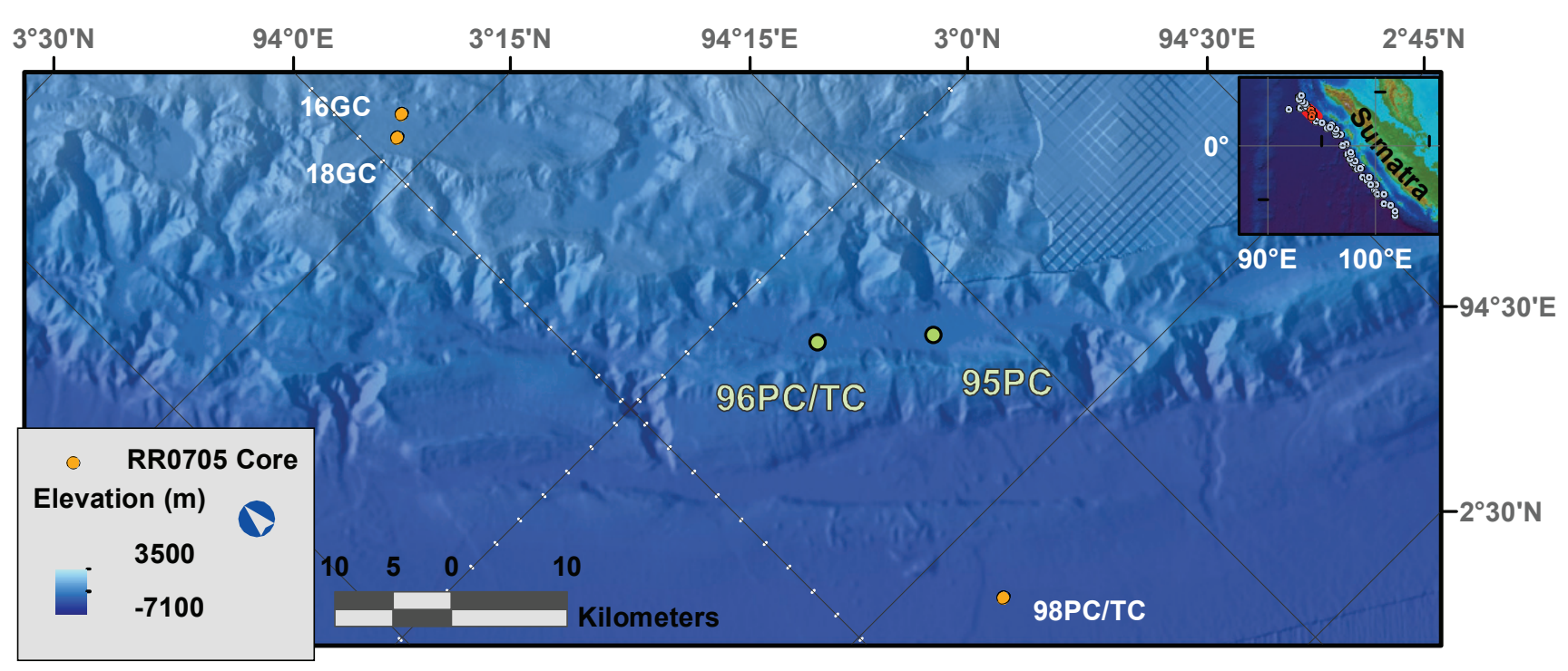

\section{E. $3.5 \mathrm{kHz}$ Seismic Data}

\section{F. Low Angle Oblique View}

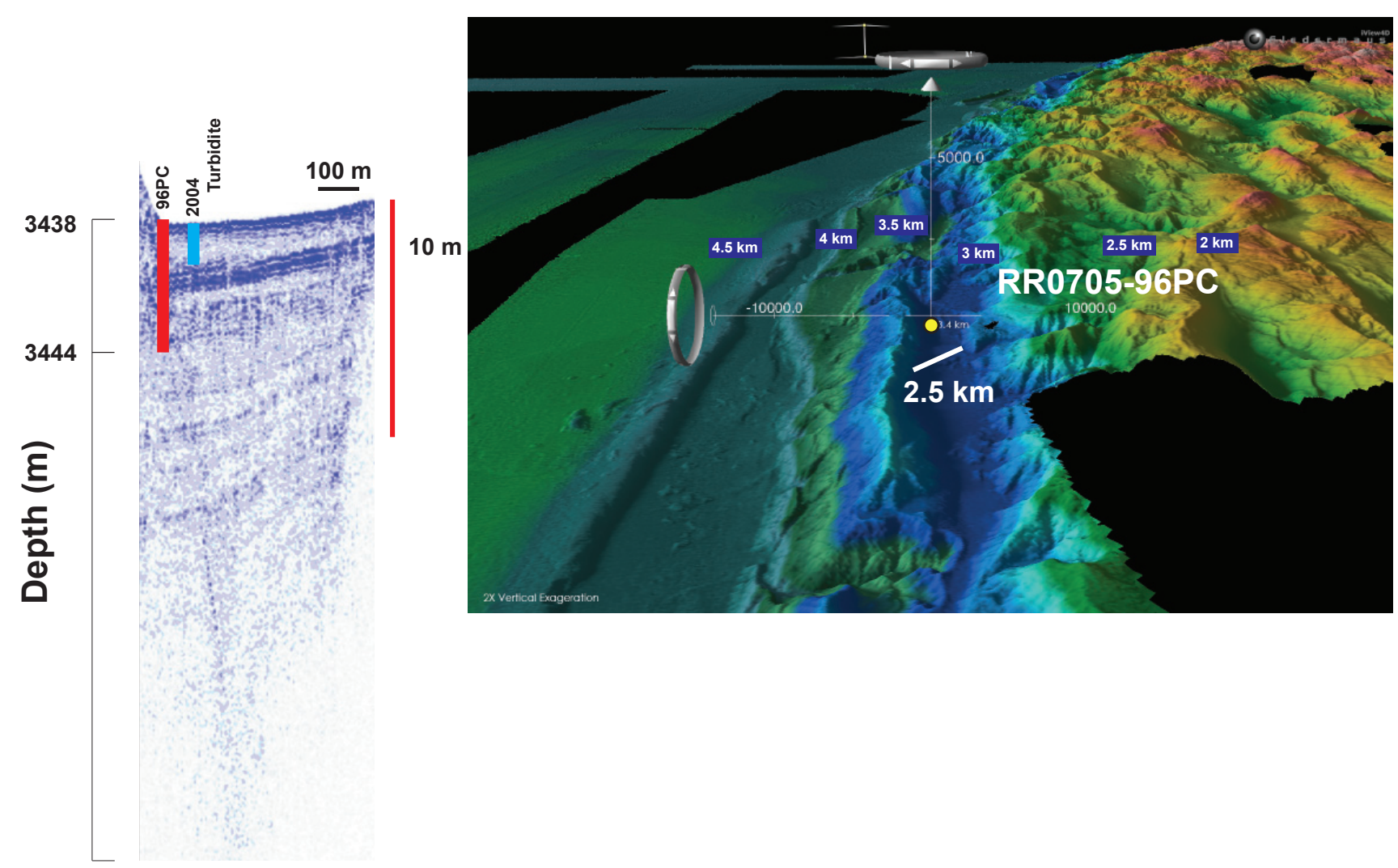

Fig. 6. (D) Core site locations for cores RR0705-96PC/TC. Inset map shows location of large map in red (northern margin) and cores in main map are orange dots (E) $3.5 \mathrm{kHz}$ CHIRP seismic data collected at core sites are processed in SioSeis and plotted in SeiSee (seismic envelope). Core location is designated by a red line scaled to core length. (F) Low angle oblique view of core site, designated by yellow dot. Due to nature of oblique maps, the scale is only relevant nearest the core location. 


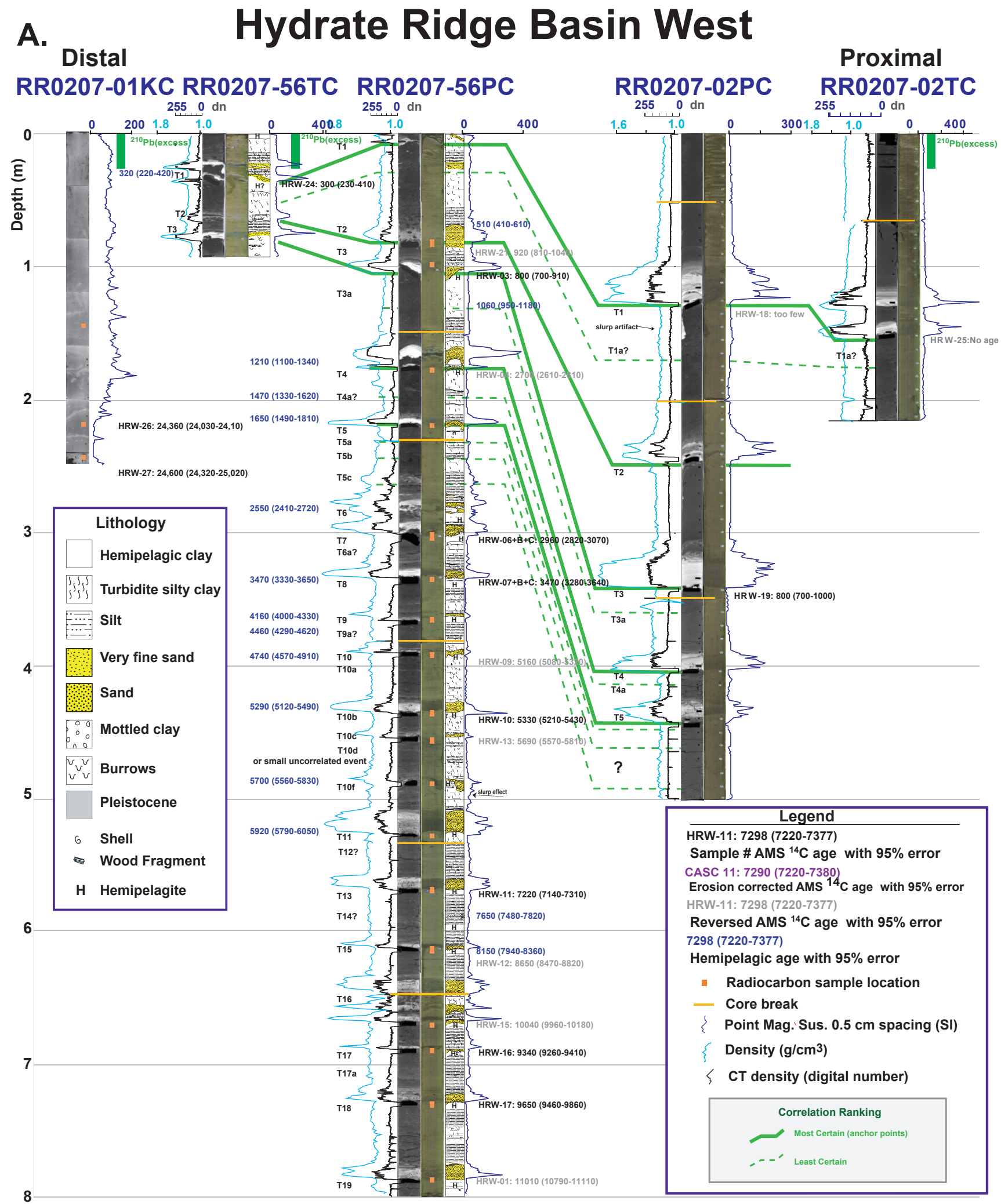

Fig. 7. Cascadia slope basin cores at Hydrate Ridge West Basin: RR0207-01KC, 56PC/TC, and 02PC/TC (Fig. 3). (A) Site-correlation diagram for Hydrate Ridge Basin West (HRBW) cores. Individual coarse pulses in these turbidites, $02 \mathrm{PC} / \mathrm{TC}$ in particular, are well defined, consistent with their proximal setting. MSCL data are plotted along with CT density: gamma density in light blue, CT density in black, and magnetic susceptibility in dark blue. Calibrated radiocarbon ages (Goldfinger et al., 2012) are reported with 95\% error. ${ }^{210} \mathrm{~Pb}$ activity ("excess"), measured in some cores, shows to what depth recent sediments were deposited (approx. 150 yr; Noller, 2000). 

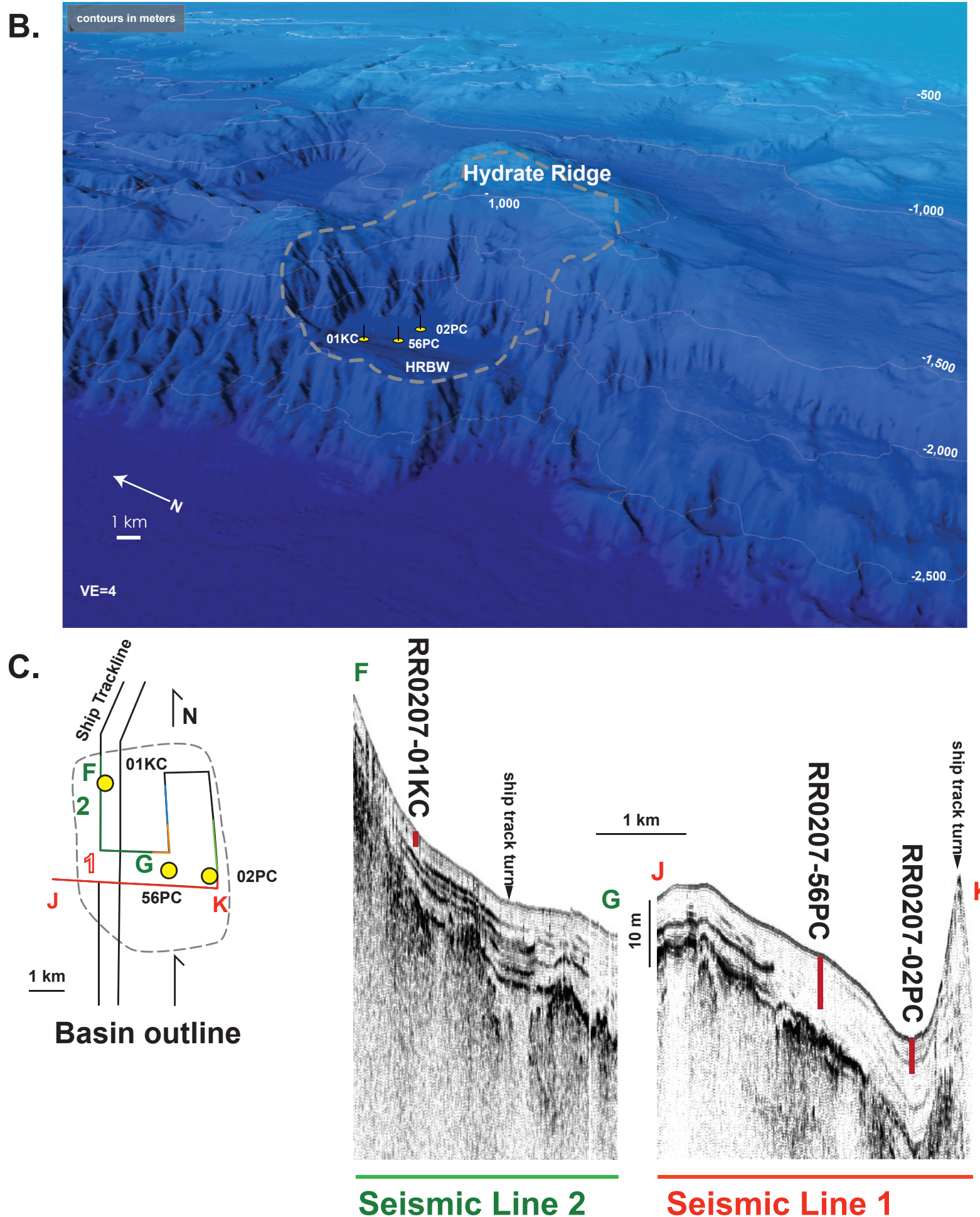

Fig. 7. (B) Low angle oblique view of core sites. (C) $3.5 \mathrm{kHz}$ seismic data collected during transit for our coring cruise TN0909 are processed with Sioseis and the envelope is plotted in Seisee. Inset map: Track lines associated with seismic data are plotted with colors that match the seismic data. Core location is designated by a red line scaled to core length. Cores are plotted in yellow and basin is outlined as dashed grey line. 
A. Sumatra Trench Cores

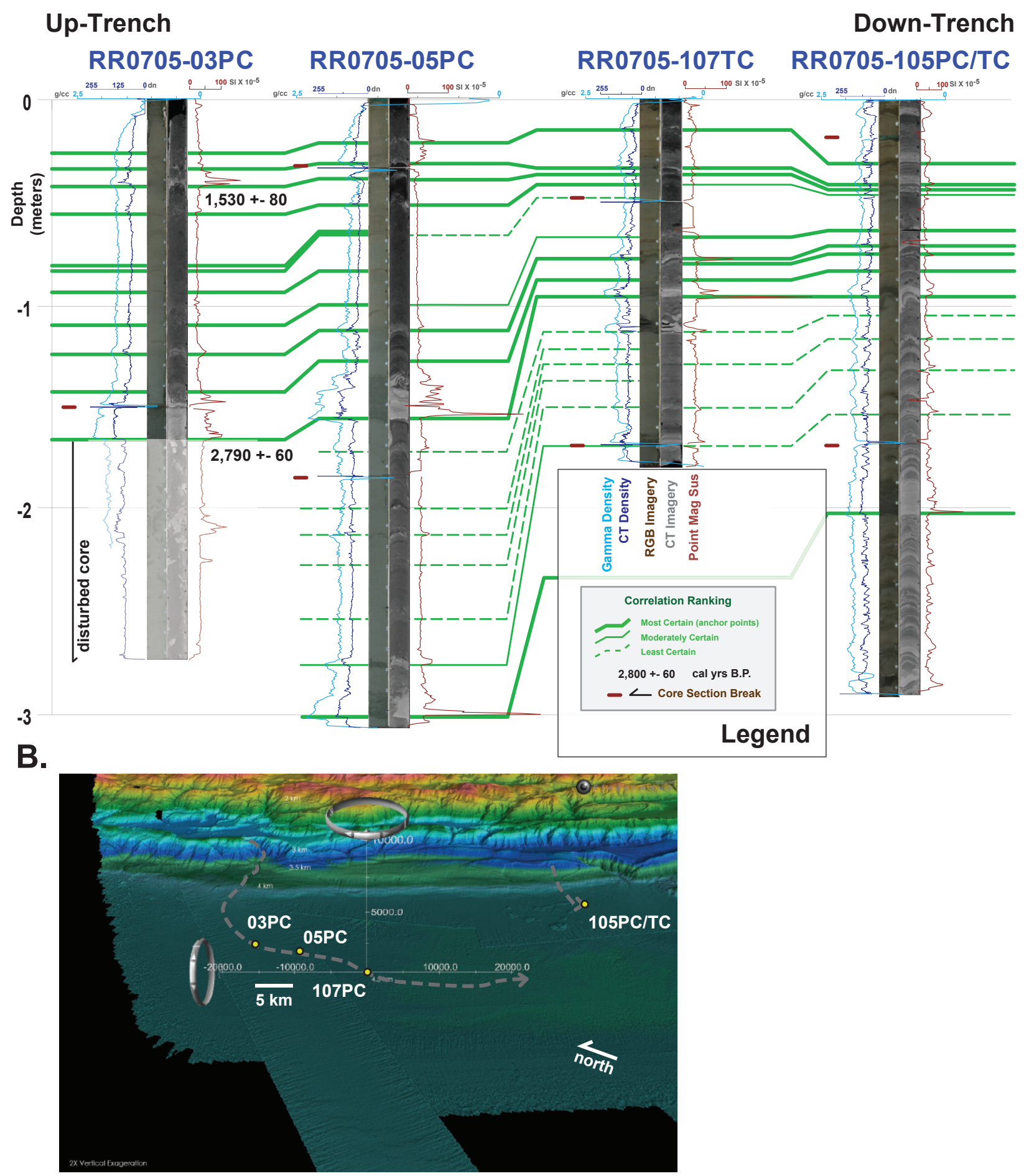

Fig. 8. Sumatra trench cores RR0705-03PC, RR0705-05PC, RR0705-107TC and RR0705-105PC/TC (Fig. 3). (A) Cores are plotted in same configuration as Fig. 2. Radiocarbon ages are displayed with $95 \%$ error. These ages are from below correlated turbidites in the slope core 108PC/TC (Table S1). (B) Low angle oblique view of core sites. Flow pathway from landslide source area to core sites is designated by a grey dashed line. Cores sites are plotted as yellow dots. 

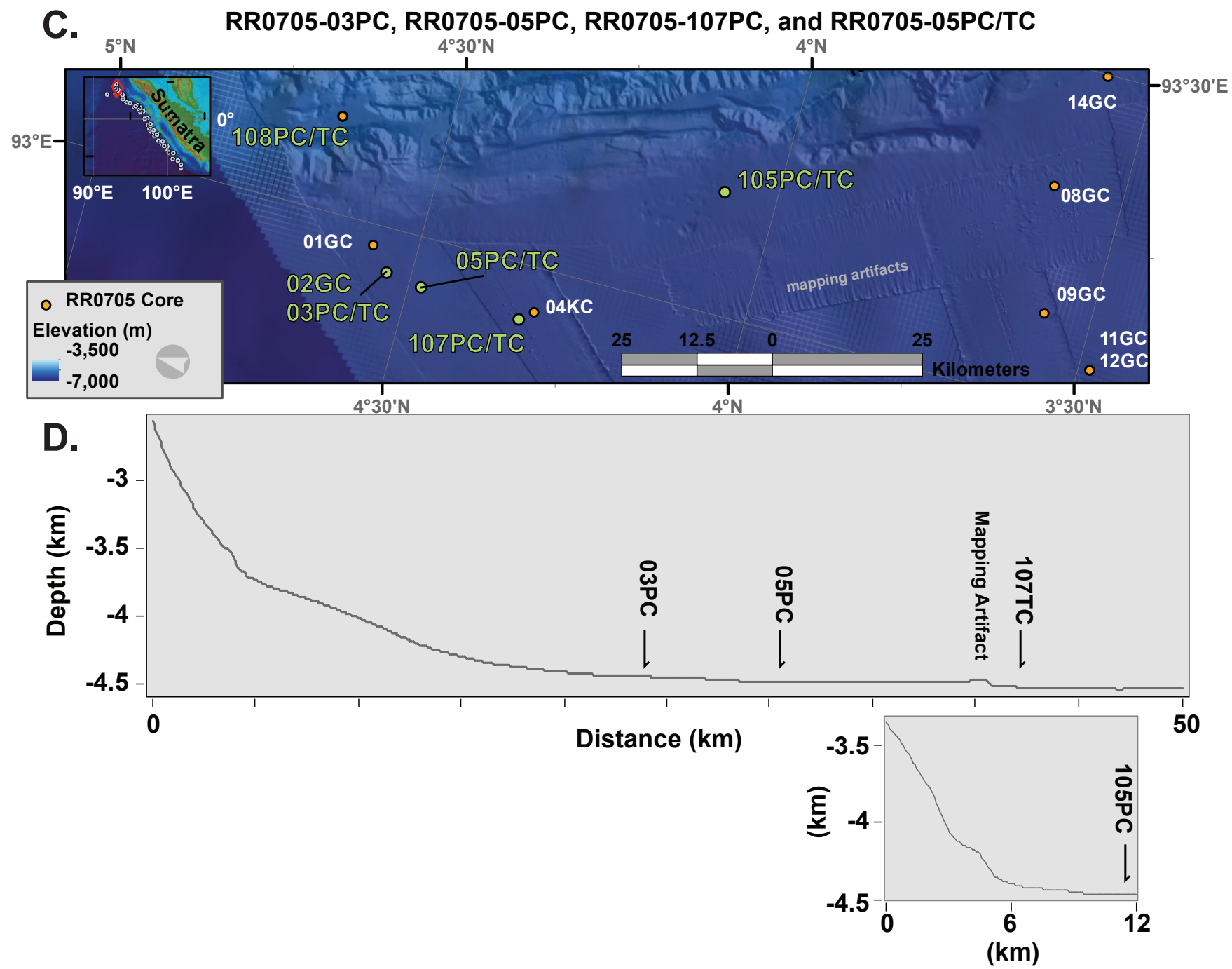

E.

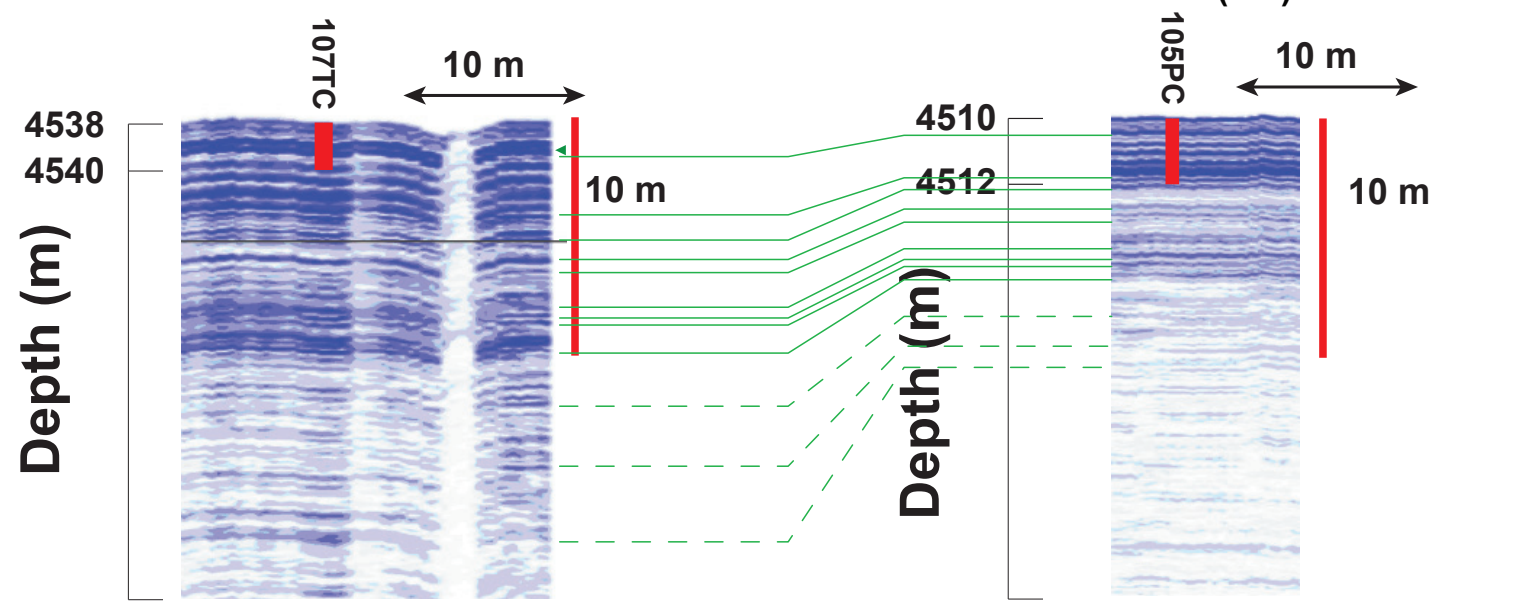

Fig. 8. (C) Map showing core locations. (D) Flow pathway profiles as shown in (B) are plotted with elevation versus distance. Core locations are labeled. (E) $3.5 \mathrm{kHz}$ CHIRP seismic data collected at core sites are processed in SioSeis and plotted in SeiSee (seismic envelope). Acoustically opaque sediments are marked by a green arrow. Core locations are designated by a red line scaled to core length. The profile is smaller than the dot that designates the core location in $(\mathbf{B})$. 


\section{Juan de Fuca Canyon / Cascadia Channel Cores A. Up-Channel M9907-12TC M9907-12PC Down-Channel}

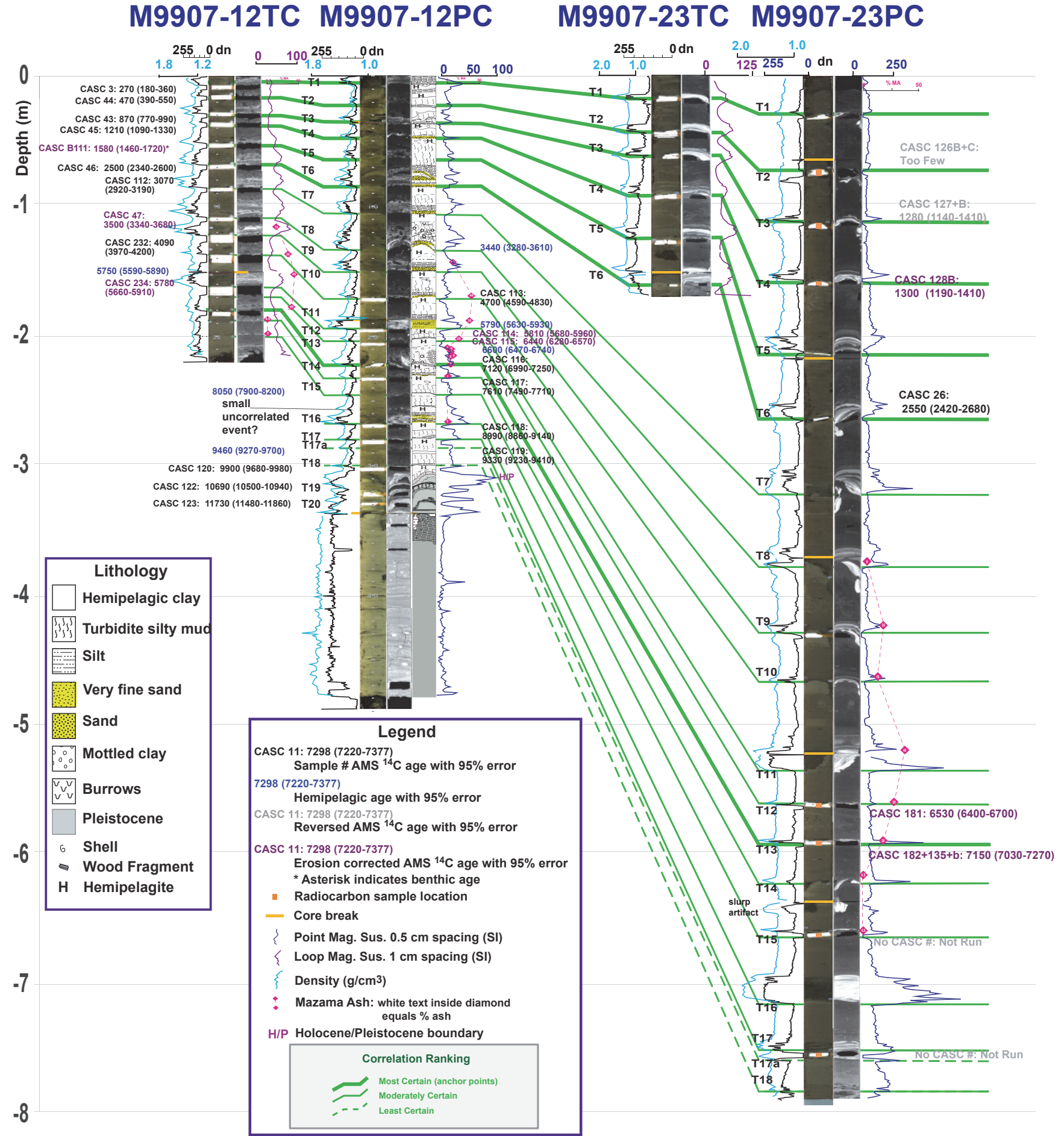

Fig. 9. Cascadia trench: Juan de Fuca (JDF) channel (a tributary to Cascadia channel) and Cascadia channel cores MM9907-12PC and M9907-23PC/TC (Fig. 4; Goldfinger et al., 2012). (A) Correlation diagram for cores $12 \mathrm{PC}$ and $23 \mathrm{PC}$ with core data plotted with same configuration as Fig. 7. 
B.
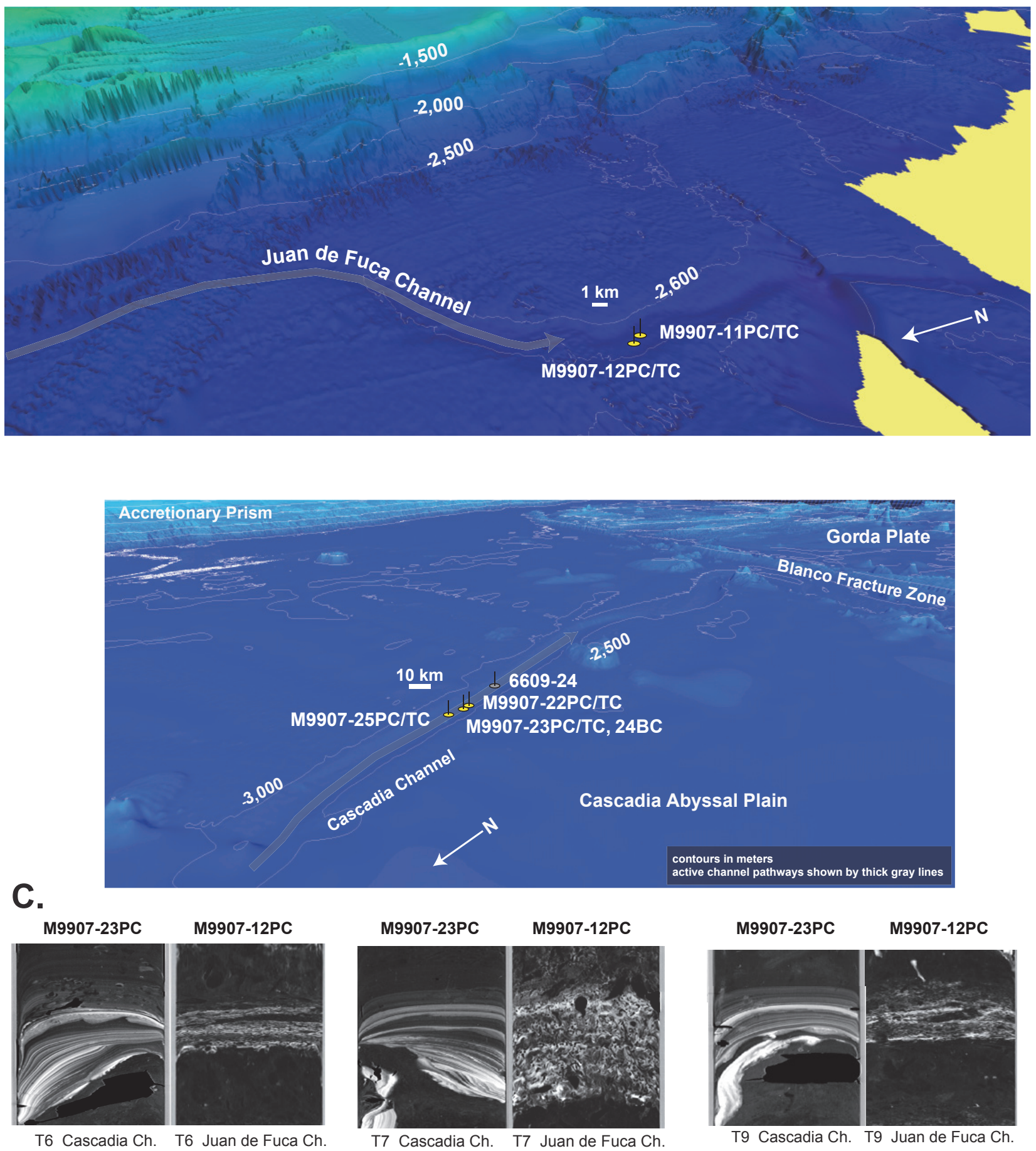

Fig. 9. (B) Low angle oblique view of core sites. Because the map is oblique, the scale bar is only relevant nearest the core locations. (C) CT scan data from cores $23 \mathrm{PC}$ (Cascadia channel) and 12PC (Juan de Fuca channel) are compared for three well-correlated turbidites T-6, T-7, and T-9. The JDF imagery is "flattened" to the upper and lower sand contacts of the corresponding Cascadia channel units. These examples show the relatively unchanged internal structure of these typical events after passing the confluence at Willapa channel and $\sim 350 \mathrm{~km}$ of transport. JDF channel imagery is degraded significantly by numerous small gas evolution voids, but the structural similarity is still evident. The primary structure of two pulses and three pulses for T9 and T6, respectively, is matched by density and magnetic peaks. T7 shows more pulsing ( $~ 7)$ than is resolvable with the geophysical data, but it is apparent in both cores. 


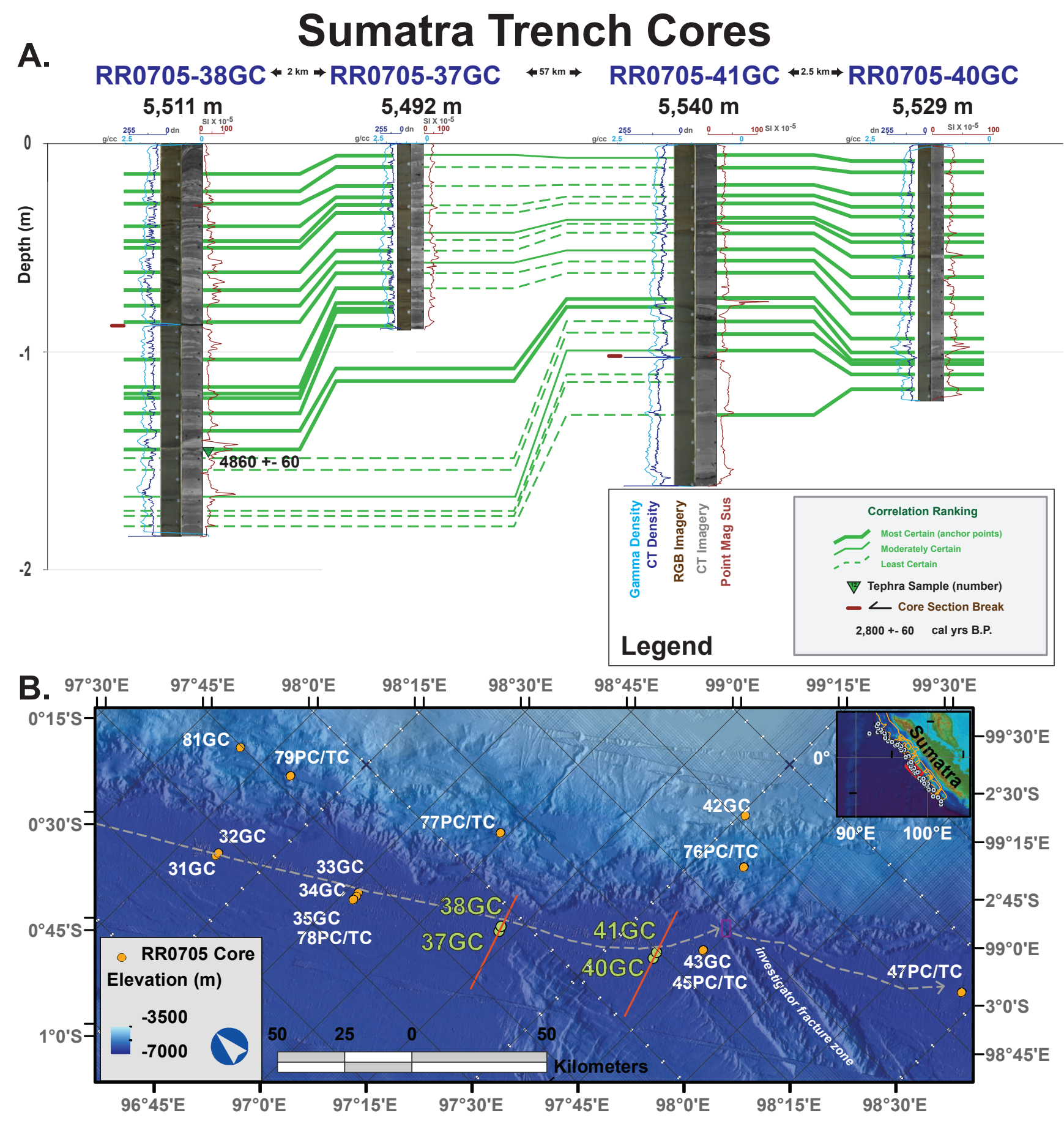

Fig. 10. Sumatra trench cores RR0705-38GC, RR0705-37GC, RR0705-41GC, and RR0705-40GC (Fig. 3). (A) Correlation of these cores is shown with green tie lines and core data are plotted with the same configuration as Fig. 2. The radiocarbon age is from hemipelagic sediment underlying the correlated tephra in core $79 \mathrm{PC}$ and reported with $95 \%$ error (Salisbury et al., 2012; Table S1). (B) Core location map with cores plotted as orange circles over multibeam bathymetry, cores 37, 38, 40, and 41 in green (Ladage et al., 2006). Inset map shows location of large map in red (central margin). Dashed grey line shows general trench axis as a potential flow pathway. Purple rectangle shows where the IFZ intersects the trench to isolate these basins (flow pathway barrier). 


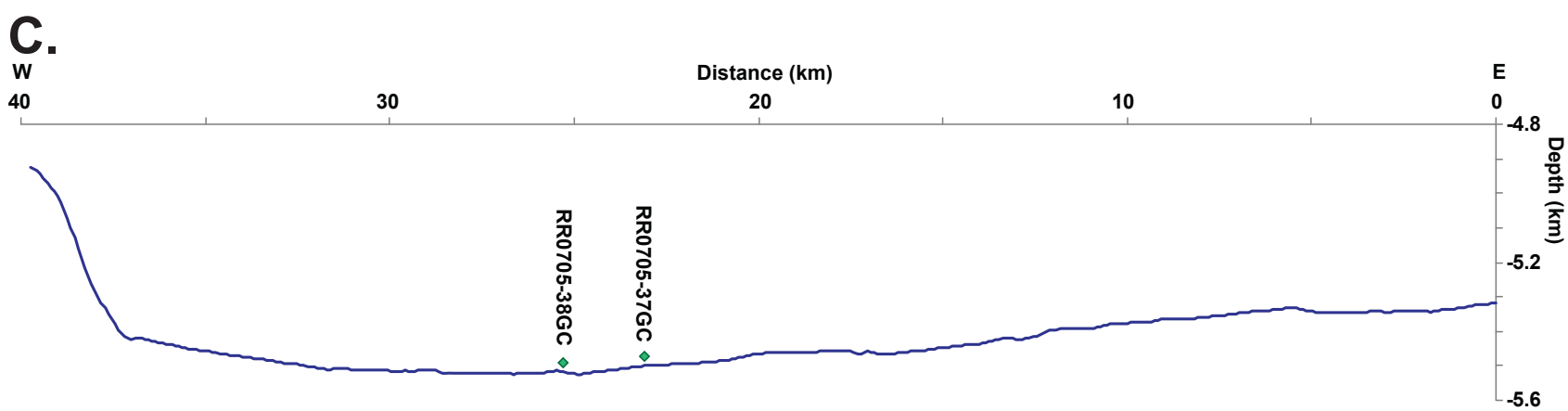

\begin{tabular}{ccccc} 
W & & Distance $(\mathbf{k m})$ & 20 & \\
40 & 30 & 10 & 0 \\
\hline
\end{tabular}

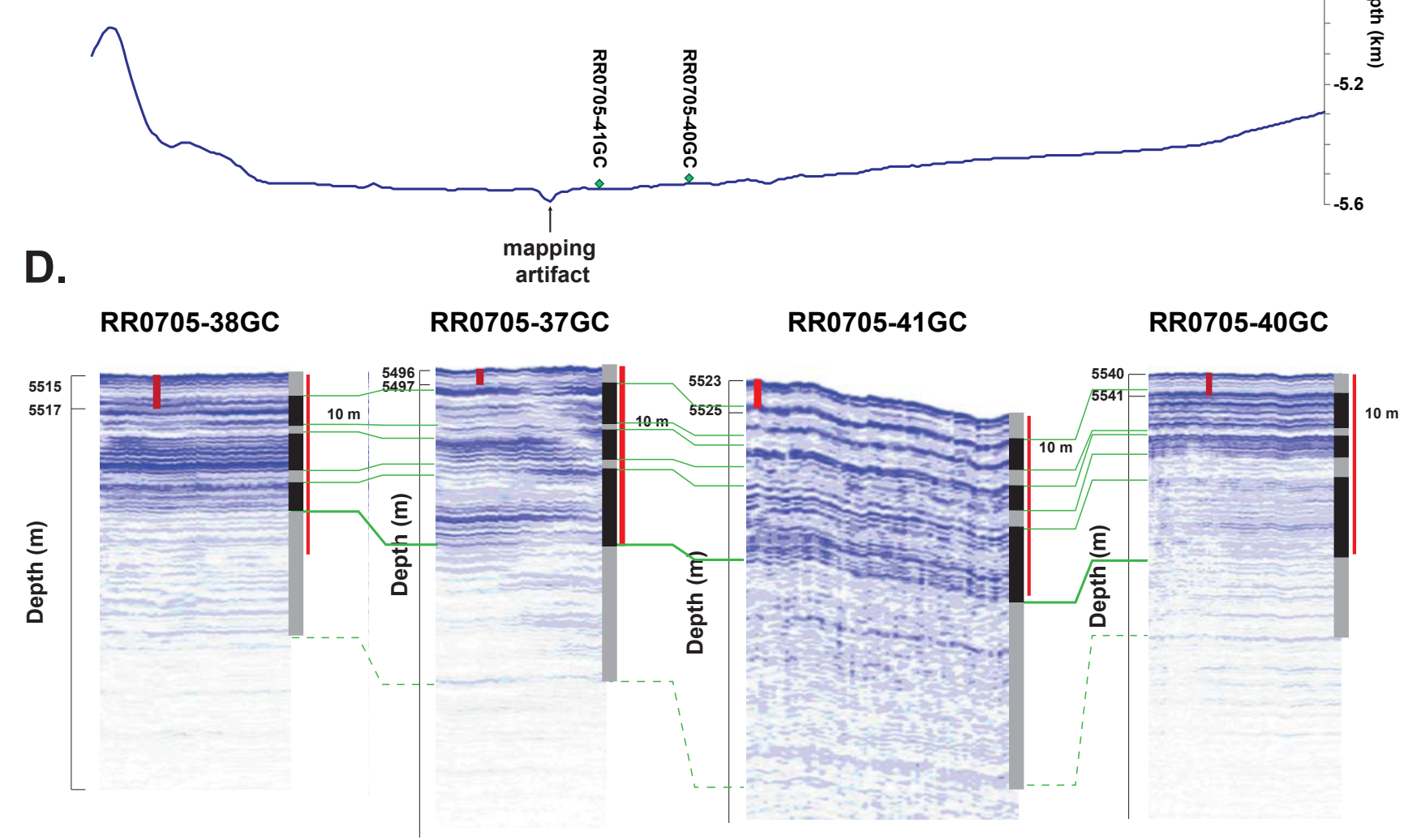

Fig. 10. (C) Elevation is plotted versus distance along a strike line aligned to core pairs. Core locations are labeled in green. Profile locations are plotted as red lines in (B, D) $3.5 \mathrm{kHz}$ CHIRP seismic data collected at core sites are processed in SioSeis and plotted in SeiSee (seismic envelope). Core locations are designated by a red line scaled to core length. Horizontal extent of seismic data are unresolvable at the scale in (A). Seismic data for cores $37 \mathrm{GC}$, 38GC, and 40GC were collected while the ship maintained position over the core location. Seismic data for core $41 \mathrm{GC}$ were collected while leaving the core site, so the horizontal scale is shown. 


\section{Results}

Here we first discuss selected core sites and then compare piggyback basin records of seismoturbidites from Sumatra and Cascadia. We then similarly compare core sites from the trenches of both Sumatra and Cascadia. Slope basin and trench settings provide different forcing factors, so we also used this distinction in the organization of our paper. Slope basins are generally more proximal to their source, but not always, depending upon the setting. Trench cores may be more distal (in the trench where there are channels) or proximal (in the trench where there are no channels). Core suffixes are as follows: piston cores (PC), jumbo cores (JC), trigger cores (TC), gravity cores (GC), Kasten cores (KC), box cores (BC), and multi cores (MC). Piston coring includes both the PC or JC (depending on how the cruise scientists label them, technically they are the same, $\mathrm{PC}$ is our preference) and the $\mathrm{TC}$, so they generally come in pairs.

\subsection{Slope basin systems}

\subsubsection{Sumatra: basins}

Core 104PC/TC is located in a northwest striking, $2-3 \mathrm{~km}$ wide, $\sim 40 \mathrm{~km}$ long basin formed on the landward side of a landward vergent fold in the Aceh Segment (Kopp et al., 2008). The basin is filled with locally derived sediment sourced from the surrounding anticlinal folds. Sediment sources on the eastern flank of the basin are steep at a $\sim 10^{\circ}$ slope. Core $103 \mathrm{PC} / \mathrm{TC}$ is located in a similarly formed basin, though the bounding folds are more disrupted by erosional systems with more complex geomorphology. This basin is not linearly shaped like the 104PC/TC basin and the core is located in the center of a $3 \mathrm{~km}$ wide basin floor. Core $96 \mathrm{PC} / \mathrm{TC}$ is located in a $\sim 3 \mathrm{~km}$ wide, $\sim 35 \mathrm{~km}$ long, northwest striking basin also formed on the eastern flank of a landward vergent fold.

The lithostratigraphy of the northern Sumatra slope cores is dominated by coarse grained Ta-Te turbidites (Bouma, 1962) and fine grained turbidites (Bouma, 1962; Stow and Piper, 1984) interbedded with massive hemipelagic mud and less common tephras. Bioturbation is common and coreinduced deformation is observed in some cores. Turbidites are composed of coarse silt to coarse sand bases, with fining upward sand and silt to clay sub-units, with the addition of abundant forams in slope cores (all of which are above the $\sim 4200 \mathrm{~m}$ deep CCD). The coarse fraction is composed of mica and quartz grains with rare mafics, consistent with the well-known and mature Himalayan source of the accreting Bengal and Nicobar fans (Stow et al., 1990). Some slope core basal turbidite sub-units are composed of foraminiferal hash. Sand sub-units commonly range in thickness from 0.5 to $\sim 20 \mathrm{~cm}$ and are laminated and cross bedded, commonly underlying massive sand units. Rare thicker sand sub-units range from $\sim 50$ to $\sim 100 \mathrm{~cm}$ thick. Finer material is composed of silt to clay sized particles. $0.5-$ to $10.5-\mathrm{cm}$ thick primary tephras are rare and can be correlated between sites using electron microprobe and laser ablation Inductively Coupled Plasma Mass Spectrometer (ICPMS) data (Salisbury et al., 2012), in the Siberut segment (Kopp et al., 2008).

Figures 5 and 6 show core, CHIRP seismic, and bathymetric data for cores 104PC/TC, 103PC/TC, and 96PC/TC. Cores 104, 103, and 96 are in sedimentologically isolated basins within $350 \mathrm{~km}$ of each other. The light-grey sand bases of turbidites are easily identified and MSCL magnetic and density maxima correlate well with the CT density maxima and grain size peaks. CT data permit a refined view of the detailed structure of the turbidites and the effects of core disturbance and basal erosion. Gamma and magnetic data reflect signals that average the effects of core disturbance as measurements are made at regular intervals, with measurement volumes perpendicular to the core length. Deformed sediment may no longer have horizontally layered strata (commonly concave downward, when the edges of the core are dragged down by the core liner during coring, Skinner and McCave, 2003). Particle size measurements, plotted in green (Fig. 6a) show a good correspondence to the MSCL data, supporting the use of them as proxies for grain size. Overall (total) sedimentation rates for these cores range from $52 \mathrm{~cm} \mathrm{ka}^{-1}$ for $103 \mathrm{PC}$, to $97 \mathrm{~cm} \mathrm{ka}^{-1}$ for core $104 \mathrm{PC}$, to $284 \mathrm{~cm} \mathrm{ka}^{-1}$ for $96 \mathrm{PC} / \mathrm{TC}$. We correlate these strata using integrated stratigraphic correlation techniques, including visual lithostratigraphic description (color, texture, and structure, etc.), computed tomography (CT) image analysis, and core log "wiggle matching" of MSCL geophysical data. We grade the certainty of our correlations with line thickness and line type (solid or dashed) in our figures. The correlations with higher certainty have thicker and solid tie lines.

\subsubsection{Cascadia: Hydrate Ridge Basin West (HRBW)}

Hydrate Ridge is a composite thrust ridge formed from seaward and landward vergent thrust faults (Johnson et al., 2005) within the lower slope of the Cascadia accretionary wedge on the central Oregon continental margin (Fig. 7c). The basin flanked on the east and west by slope basins. The isolation of the western slope basin from any canyon or channel system sourced to the east indicates that sedimentation in the slope basin may only be local submarine slope failures of the surrounding bathymetric highs (Hydrate Ridge itself), also supported by the lack of transported Mazama ash in the basin (Goldfinger et al., 2012). The most likely sedimenttransport pathway into the basin is a small submarine canyon that cuts into the western flank of northern Hydrate Ridge, which is on the eastern side of the basin (Fig. 7b); however, several other smaller potential pathways exist from the east and from the north, as well as the broad steep open slopes of the western flank of Hydrate Ridge. These slopes are unconsolidated sandy turbidites uplifted by thrust faulting, and observed directly on Alvin dives 1898-1909 and 2043-2055 
(Kulm et al., 1986). Hydrate Ridge Basin West is isolated from all terrestrial and shallow water sediment sources, and thus provides an independent environment in which Cascadia turbidites have been recorded (Goldfinger et al., 2012).

The textural and mineralogical details of the turbidites in Cascadia Channel (Griggs et al., 1969; Duncan, 1968), Astoria Fan (Carlson, 1967; Nelson, 1968; Carlson and Nelson, 1969; Nelson, 1976), and regionally (Duncan, 1968; Duncan and Kulm, 1970) are well described. Cascadia turbidites, like those in cores in HRBW, are characterized by upward fining sequences of sand, silt, and clay, with multiple amalgamated pulses, sharp bases, and upward fining of individual sand/silt pulses, when present. These deposits are turbidites (Bouma, 1962) exhibiting Ta-Te divisions, although rarely are all divisions present in a single deposit. Numbers of mud turbidites are observed, primarily along the southern Cascadia margin, and these commonly include further subdivisions of Piper (1978): laminated silt D, laminated mud E1, graded mud E2, and ungraded mud E3 (Goldfinger et al., 2013). The mud turbidites are distinguished from other fine deposits by their sharp bases, organized internal structure, and fining upward sequences. They are well characterized using the schemes of Bouma (1962) and Piper (1978).

\subsection{Trench and abyssal systems}

\subsubsection{Sumatra: trench}

Turbidity current pathways in the trench offshore Sumatra are sourced mostly from the local continental margin slope. The Sumatra outer slope lacks major canyon systems delivering large sediment loads, thus the numerous smaller canyons deliver much more modest loads to small fan aprons in the trench which have no unifying channel system. The SASZ trench channel systems that are evident are not longer than $\sim 100 \mathrm{~km}$, averaging $7 \mathrm{~km}$.

While there are relict turbidity current channels on the incoming India-Australia plate, these channels are not found in the axis of the trench so probably do not capture sediment flows sourced from the present accretionary prism. For example, at the latitude of this study, the Box Channel of Moore et al. (1976) is instead located on the outer rise of the flexing India-Australia plate, flowing downslope towards the Ninetyeast ridge. This is the only potentially active channel in the eastern Bengal Fan, as mapped by Bandopadhyay and Bandopadhyay (1999). Further south, normal faults in the incoming plate disrupt other channels that are older than the Box Channel. In contrast, channels in Cascadia are related to localized high sediment discharge during glacial periods when the shelf was narrow and fluvial systems were directly connected to submarine canyons, so channel systems are mostly relict Pleistocene systems in which modern turbidity currents flow (Nelson et al., 2009; exceptions discussed in Goldfinger et al., 2012).
Cores 03PC, 05PC, 107TC, and 105PC/TC are located near the axis of the trench in the northern margin offshore Sumatra (Fig. 8). These cores are fed by a channel leading from the base of the slope. The channel is formed as the result of recurrent slope failures from a landslide amphitheater on the western limb of the landward vergent second ridge at $4^{\circ} 34^{\prime} \mathrm{N}$. This channel initially is $\sim 1 \mathrm{~km}$ wide and rapidly widens and loses definition in the trench. The channel is only resolvable in existing bathymetry near the base of this nearest source canyon. Upper slopes of the canyon are much steeper, approaching $5^{\circ}$. At the core sites, the channel follows the base of a partially buried, east-facing, north-striking fault in the downgoing plate. Unlike more longer lived channel systems, like the Box Channel of Moore et al. (1976) or the Cascadia Channel (Nelson et al., 2000), the channel at the core sites does not appear to have a rectangular cross section to confine flow.

Cores 03PC/TC, 05PC/TC, 107TC, and 105PC/TC contain coarse sand and coarse silt turbidites, ranging in thickness from $\sim 5$ to $\sim 30 \mathrm{~cm}$. Seismic data show the turbidite (with basal depth of $95 \mathrm{~cm}$ in core 107TC) as acoustically opaque, labeled as a green arrow in Fig. 8e. Using ages from correlated deposits in the slope core RR0705-108PC (Document 1 in the Supplement), overall sedimentation rates for these cores range from $53 \mathrm{~cm} \mathrm{ka}^{-1}$ for $03 \mathrm{PC}$ and $05 \mathrm{PC}$ to $35 \mathrm{~cm} \mathrm{ka}^{-1}$ for core 107TC. Ages plotted alongside 03PC come directly from the ages in core 108PC.

\subsubsection{Cascadia: Cascadia channel system}

Cascadia has well-developed canyons and slope channels that link slope basins with Pleistocene channels formed during sea-level low stands when connected to terrestrial sediment sources (Nelson et al., 2000). These canyons and slope channels in the north have lower channel gradients and form channel systems that traverse the abyssal plain draining towards the south. The southern margin lacks a Pleistocene glacial history so does not have large fans like in the north. Because of the lack of large fans filling the trench and the steeper slope angle of the seaward vergent prism, plunge pools and base of slope aprons dominate the base of slope environment of the southern margin (Nelson et al., 2000).

Juan de Fuca Canyon originates at the Juan de Fuca Strait and, to a lesser extent, likely receives input from coastal rivers in northern Washington. Juan de Fuca canyon has a low gradient and meanders through the growing anticlines of the broad continental slope (Goldfinger et al., 2012). Two branches of the Juan de Fuca Canyon exit the continental slope separately and join as a channel at the base of the slope off northern Washington at the head of the Nitinat Fan. Juan de Fuca Channel then bends to the southwest as part of the Nitinat Fan, which apparently has only one primary active Holocene distributary channel in the upper fan system. Core $12 \mathrm{PC} / \mathrm{TC}$ was collected in the main channel (Figs. 3 and 9). 
Juan de Fuca and Willapa Channels (also comprising the input from Quillayute, Grays, and Quinault Canyons) meet on the southwestern part of Nitinat Fan to form Cascadia Channel. Cascadia deep-sea channel crosses Cascadia Basin, then enters the Blanco fracture zone (Fig. 3) and continues hundreds of kilometers into Tufts Abyssal Plain. This turbidity-current pathway traverses $\sim 1000 \mathrm{~km}$ of Cascadia Basin and has remained open throughout the late Quaternary up to the present (Nelson et al., 2009; Goldfinger et al., 2012). The active pathway is verified by the occurrence of the youngest turbidite, with an age of 270 (360-180) cal yr BP likely corresponding to the $1700 \mathrm{AD}$ Cascadia subduction zone earthquake in core $23 \mathrm{PC} / \mathrm{TC}$, collected in Cascadia channel $30 \mathrm{~km}$ north of where the channel enters the Blanco fracture zone (Figs. 3 and 9).

Turbidites in core 12PC range in thickness from 5 to $25 \mathrm{~cm}$ and are well bioturbated, except for the coarsest and thickest turbidites. Turbidites in core 23PC range in thickness from 20 to $40 \mathrm{~cm}$. These turbidites are generally less bioturbated, except in the units with finest particle size range. Stratal thickness in core 12PC is less than half of that in more distal core 23PC. The overall sedimentation rate for core 12PC is $\sim 32 \mathrm{~cm} \mathrm{ka}^{-1}$, while the rate at core $23 \mathrm{PC}$ is $\sim 84 \mathrm{~cm} \mathrm{ka}^{-1}$.

\subsubsection{Sumatra: trench}

The slope offshore Sumatra reflects the lack of a glacial history in this region as there are no locally sourced large fan systems associated with slope sedimentary systems. Most slope canyons deliver sediment to base of slope apron fans in the compartmentalized trench. In some locations the frontal thrust is blocking margin slope sediment delivery directly to the trench (Ladage et al., 2006; Kopp et al., 2008) and fans are smaller with few resolvable fan channels. Once the sediment flows reach the base of the slope, they may be distributed southward within the trench segments based on the regional slope of the trench axis. Current flow in the trench has limited distribution due to blockage of the trench axis by subducting transverse fracture zones and unnamed ridges at $-2.23^{\circ}$ and $-3.74^{\circ} \mathrm{S}$.

Cores $38 \mathrm{GC}, 37 \mathrm{GC}, 41 \mathrm{GC}$, and $40 \mathrm{GC}$ are located in the Siberut Segment (Kopp et al., 2008), in the trench axis, up-slope (up-trench) from the Investigator fracture zone (Fig. 10). Each pair is $\sim 10 \mathrm{~km}$ from the base of the margin slope. While each core pair only spans a $\sim 3 \mathrm{~km}$ trenchnormal transect, the more proximal cores were collected near the axis of the trench and the other cores located up-slope, more distally on the outer trench wall. Figure 10 shows these cores with green tie lines indicating our correlations in the figures. These correlations are made with the same methods described for all correlations in this paper, using lithologic descriptions and flattening stratigraphic horizons using the turbidite fingerprints based on core geophysical data. Trench normal topographic profiles were constructed using a $90 \mathrm{~m}$ bathymetric data set (Fig. 10b).
All four cores, 38GC, 37GC, 41GC, and 40GC, contain silt and sandy turbidites interbedded with hemipelagic muds. $38 \mathrm{GC}$ and $41 \mathrm{GC}$ contain a tephra (demarcated with inverted green triangle Fig. 10) correlated with 7 other cores in the region using major and trace elemental analyses (Salisbury et al., 2012). Ages from RR0705-79PC provide a robust age for this tephra at $4860 \pm 60 \mathrm{cal}$ yr BP, so the age from core 79PC is projected onto these cores (Salisbury et al., 2012; Fig. 10). Using the stratigraphic series and geophysical correlation, we further correlate this tephra and turbidites spanning over $280 \mathrm{~km}$ along the trench (Fig. S3), including correlations across the IFZ to core RR0705-45PC and possibly to RR0705-47PC. Sedimentation rates in these cores ranges from 15 to $33 \mathrm{~cm} \mathrm{ka}^{-1}$.

\subsubsection{Cascadia: base of slope apron fan (Rogue)}

The southern Cascadia margin lacks the dominant Pleistocene regional fan systems, found in the north, in favor of base of slope apron fans. The steeper gradients of the slope channels in the south, due in part to the lack of fans that fill the trench, are responsible for the presence of base of slope apron fans and plunge pools (Nelson et al., 1986, 2000). We examine the base of slope apron cores at the base of Rogue Canyon, cores 01JC, 30PC, and 31PC.

These three cores were collected at the base of the canyon where there is a small ( $10 \mathrm{~km}$ wide, $50 \mathrm{~m}$ thick) base of slope apron fan. The cores are positioned approximately beyond the edge of the fan on the flat trench floor. Figure S2 shows these core data and the seismic profile compiled and processed in SioSeis. There is very little variation (not more than $\sim 5-10 \%$ ) in stratal thickness between these cores. Seismic facies thicknesses also do not vary though a slight thickening in the distal direction can be seen. This thickening is possibly due to bypassing of proximal cores due to a hydraulic jump at the base of the slope (Goldfinger et al., 2013). Coarse and fine grained turbidites range in thickness from 15 to $50 \mathrm{~cm}$, with an overall sedimentation rate of $\sim 67 \mathrm{~cm} \mathrm{ka}^{-1}$.

\section{Discussion}

Here we discuss how sedimentation varies between sites, and how physical factors may influence turbidite sedimentation in the Sumatra and Cascadia systems in piggyback slope basins and trench settings. While earthquake triggering is not the principle focus of this paper, we use our correlations as a stratigraphic framework with which to discuss the variations in stratigraphy. Correlations for seismoturbidites, based on geophysical fingerprinting and lithostratigraphic interpretations, are shown as green lines in the figures. The stratigraphic sequences and individual units with the most unique geophysical "fingerprints" (Goldfinger et al., 2007, 2008, 2012) carry the strongest correlative weight and act as "anchor points" for these correlations (Fig. 4). The correlations 
between anchor points vary in quality and rely more heavily on the similarity of stratigraphic sequences. These correlations are important as they allow us to make comparisons between coeval deposits in different cores.

\subsection{Sumatra systems}

In Sumatra, the geologic setting contributes in several ways to localize sedimentation in the slope basins and in the trench. All but two basin core sites (cores 85PC/TC and 92PC/TC; Fig. S3) from cruise RR0705 are isolated from sedimentation transported from shallower and terrestrial sources, reducing the susceptibility to processes other than earthquakes (Goldfinger et al., 2012). These other settings are more susceptible to other triggering processes because they are either shallower or near terrigenous sources, where those other trigger processes take place (storm and tsunami wave base liquefaction, storm wave resuspension, or hyperpycnal flow from flooding). The uniqueness of each deposit in a core and the similarity of a deposit from one core to the next, combined with the isolation of the sites from terrestrial sources and from one another, argue for a common trigger that leaves a record of each event in every core. However, given the relatively smaller (150 to $\left.1500 \mathrm{~km}^{2}\right)$ and more proximal source areas compared to trench sites, site factors could contribute more significantly to the turbidite structure in slope cores. During glacial low stands, only cores in the region of Nias and Siberut islands, which were larger in area, would likely have been influenced by the increase in subaerial exposure in their source drainages. Other core locations remained isolated from terrestrial sources due to the forearc basins and deep-water catchments.

Core 104PC/TC is located on a sill at the edge of a partially enclosed basin. At $10 \mathrm{~m}$ above the surrounding basin, this low sill probably does not significantly restrict flow from the basin into the adjacent canyon system to the southeast. This core pair is also located at the base of high relief canyons (see profile Fig. 5) and distanced $250 \mathrm{~m}$ horizontally from a steep $1.5 \mathrm{~km}$ high cliff, where the upper slopes of the canyons approach $10^{\circ}$. Core 104 is thus proximal to very steep slopes, more so than other core sites. Core 104 has turbidites that characteristically have multiple $(10-30)$ laminated $(<1 \mathrm{~cm})$ silt or sand sub-units (e.g. core depth $175-205 \mathrm{~cm}$ ). We interpret the numerous small pulses within a single apparently correlative turbidite to be the result of retrogressive failure of the nearby upper canyon slopes. The "stacked" turbidite structure of thin units in this core is unique to this site as compared to interpreted correlative units at other sites. This is analogous to the turbidity currents that responded to retrogressive failures triggered by the 1929 Grand Banks earthquake (Piper and Normark, 2009).

In comparison, core $103 \mathrm{PC} / \mathrm{TC}$ (Fig. 5), only $35 \mathrm{~km}$ to the southeast of core 104, is located in the center of a $2 \mathrm{~km}$ wide, $\sim 0.5^{\circ}$ sloped, flat canyon valley. This core records a similar sequence of seismoturbidites as core 104 but also shows that the site conditions exert a secondary control on sedimentation. Upper canyons with slopes of $5-8^{\circ}$ feed this wide valley, but no channel system is resolvable given existing bathymetric data ( $50 \mathrm{~m}$ resolution). Core 103 has thin bedded (5$10 \mathrm{~cm}$ thick) sandy and silty turbidites. We interpret these to have been the result of turbidity current flows that are unconfined across the wide valley. This core location is more distal with respect to steep source areas than core 104 and apparently does not receive the retrogressive failures during each event that apparently occur on the steeper slopes above the site of core 104.

While turbidites in the cores discussed in this section likely have primary structures related to the earthquake source that accounts for primary depositional structure we are correlating (Goldfinger et al., 2008, 2012), their structures also have site-related forcing. While the stratigraphic sequences correlate well overall, more local variability is apparent than in the Cascadia cores. This is likely due to the more proximal locations of the Sumatra cores. Variability due to basal erosion, heterogeneous source areas within the region, and site geomorphology would be expected at such proximal sites, regardless of the triggering mechanism.

We collected core $96 \mathrm{PC} / \mathrm{TC}$ in a northwest striking, $\sim 2^{\circ}$ sloped $3 \mathrm{~km}$ wide basin that may drain over a $50 \mathrm{~m}$ tall sill to the southeast. The basin has several basin crossing sills with elevations of 10-20 m and, based on our multibeam bathymetric interpretations, are the result of mass transport deposits sourced from the local slope to the east. These sills form small sub-basins within the larger basin. This core pair has the most expanded Holocene section of all slope basin cores collected for this study (Figs. 2 and 6). Three size classes comprise the multi-pulse silt to sandy turbidite sequences at this site. Sand-silt turbidites $20-30 \mathrm{~cm}$ thick with 3-4 pulses are interbedded with thinner, $5-10 \mathrm{~cm}$ thick, multi-pulse turbidites. The thinner turbidites are more bioturbated, as in most of our cores offshore Sumatra. The thickest turbidite in core 96 is $\sim 3.5 \mathrm{~m}$ thick, compared to less than a meter at all other core sites from the 2007 cruise. This expanded section we here interpret to be the result of ponding in the effectively undrained sub-basin.

We provide a figure that shows our lithologic logs plotted alongside the other core data, including a plot designating hemipelagites from turbidites (Fig. S4).We plot particle size for the uppermost turbidite in 96PC using a C/M plot (Passega, 1957, 1964). C/M plots are based on comparison $\mathrm{C}$, the one percentile (d99), with $\mathrm{M}$, the median grain size and can be used to infer the mode of transport and deposition (Shiki et al., 2000). 96PC C/M data are consistent with turbidites elsewhere (Passega, 1957, 1964; Shiki et al., 2000). ${ }^{210} \mathrm{~Pb}$ decay per minute data are also plotted for the sediments underlying the uppermost turbidite and show an exponential decay, supporting the recency of the overlying turbidite.

We interpret that the uppermost turbidite in cores 105, 104, and 96 is most likely the 2004 turbidite. The lack of 
hemipelagic sediment overlying this turbidite, the lack of consolidation when compared to older strata, its great thickness (over $3 \mathrm{~m}$ ) at one site, and excess ${ }^{210} \mathrm{~Pb}$ the sediments underlying the uppermost turbidite showing an exponential decay are consistent with this interpretation. Also consistent with this interpretation is the radiocarbon age of the underlying sediment of $30 \pm 30$ cal yr BP (Document 1 in the Supplement). In addition, the MSCL maxima may correlate generally with seismologic observation maxima, providing a potential direct link to the recently historic earthquake (Goldfinger et al., 2008, 2012; Fig. 6). There are mapped many accretionary prism faults (e.g. Graindorge et al., 2008) that are possible earthquake trigger sources. The megathrust remains as the single source that extends between all these core sites, so deposits that are correlated over these large distances are unlikely to be sourced from rupture on these shorter accretionary prism faults. Uncorrelated turbidites may be related to these smaller faults, but we do not have sufficient core spacing to de-confound those relations. The correlations in Fig. 5a support the seismologic interpretation for these deposits because the stratigraphic units are correlated between cores at isolated sites across a broad region.

Cores 03PC and 05PC are closely spaced and have almost identical stratal thicknesses (Fig. 8), but the more distal core pair 107PC/TC has thinner deposits. This more distal core pair was collected on the upthrown side of a normal fault. The fault probably controls turbidity current flow, with a scarp $\sim 25 \mathrm{~m}$ above the trench floor. The thinner section in these cores may be explained by the upslope position of core 107 where the turbidity currents lose energy flowing up slope, possibly similar to Barkley Canyon and Hydrate Ridge Basin West in Cascadia (Goldfinger et al., 2012).

Turbidites in these three cores are well correlated, spanning a distance of $28.5 \mathrm{~km}$ (Fig. 8). Green tie lines show the correlations and the relative confidence we have in them. We cannot test our correlations with ${ }^{14} \mathrm{C}$ age control due to the lack of datable material at trench depths, although because of our confidence in the stratigraphic correlations to nearby basin sites, we use the ages from correlated units in core 108PC to label the correlated units in core 05PC (Document 1 in the Supplement). Core 107PC has coring artifacts, therefore we use core 107TC for comparison.

Cores $37 \mathrm{GC}$ and $38 \mathrm{GC}$ are located on the western side of the trench axis, near the mouth of a slope canyon that dissects several slope basins, collecting sediment discharge sourced from these basins as the flows transport down slope (Fig. 10b). In addition, the most trenchward fold has multiple landslide amphitheaters immediately adjacent to the cores, which may further contribute to turbidity currents that reach these cores. In contrast cores 40GC and 41GC, also west of the trench axis, are located adjacent to a slope that has an incipient frontal thrust anticline. This anticline may attenuate turbidity currents sourced to the east as they flow upslope over the fold axis (Fig. 10b). Both trench pairs are on transects normal to the margin.
For cores 37GC (distal and uphill) and 38GC, both stratal thickness and seismic facies depth show a thinning of turbidite deposits in the distal and uphill direction (similar to cores $03 \mathrm{PC}, 05 \mathrm{PC}$, and 107TC). In contrast, cores 40GC (distal and uphill) and $41 \mathrm{GC}$ show a $\sim 10^{\circ}$ stratal thickening in the distal and upslope direction. Core $40 \mathrm{GC}$ is a $6.7 \mathrm{~cm}$ diameter "Benthos" gravity core, while core $41 \mathrm{GC}$ is a $10.1 \mathrm{~cm}$ diameter gravity core. The friction exerted upon layers of sediment ("soil elements," Skinner and McCave, 2003) is a combination of the shear strength of the sediment and the skinfriction between the soil element and the core barrel (Skinner and McCave, 2003). For a soil element of unit thickness, the jumbo gravity core has $50 \%$ more surface area and a proportional more friction. As more soil is cored, the additional soil elements contribute to the downward force and contribute to a cumulative vertical stress, reducing sediment compaction at the base of the core (Skinner and McCave, 2003). Yet $41 \mathrm{GC}$ is compressed and $38 \mathrm{GC}$ is expanded. Other factors that affect how sediment is cored include the smearing of sediments along the core-sediment interface and the transfer of pore pressure transfer of friction directly to the core base. It is possible that there was an hydraulic jump at the base of the slope, causing bypassing at the proximal site and thickening at the distal site (Piper and Normark, 2009; Goldfinger et al., 2013). Any of these factors can explain the difference in stratal thickness between these cores. In addition, the inter-core spacing for each of these two core pairs may be too small to explain the variation in stratal thickness alone, based on source proximity.

\subsection{Cascadia systems}

In Cascadia isolation from terrestrial sedimentation is also important for studying seismoturbidites. The shelf width, as it relates to glacial cycle sea-level fluctuation, provides a control to this suitability. During low stands, narrow shelf widths allowed connections between river mouths and their respective canyon heads. During high stands, most sites are isolated from direct terrestrial input because the shelf is wider and much of the sediment is captured and swept northward along the shelf by the north flowing winter Davidson Current (Sternberg, 1996). Because of this relation, the turbidite frequency is higher during glacial periods. The modern shelf near the Eel River is amongst the narrowest in Cascadia and turbidite frequency in these Eel Canyon cores is the highest of the entire margin, similar to low-stand times $(\sim 70 \mathrm{yr}$ recurrence interval, given 54 turbidites in $3800 \mathrm{yr}$; Goldfinger et al., 2012). This may be due to increased seismicity (including tectonic sources in addition to the subduction zone) or to direct terrestrial input. The overall sedimentation rate is also higher in the region of Eel Canyon when compared to cores more northward; Rogue cores span $12000 \mathrm{yr}$ in eight meters and Eel cores span only $3500 \mathrm{yr}$ in $4.5 \mathrm{~m}\left(67 \mathrm{~cm} \mathrm{ka}^{-1}\right.$ vs. $128 \mathrm{~cm} \mathrm{ka}^{-1}$, respectively; Goldfinger et al., 2012). 
The Holocene stratigraphic record of slope failures preserved as turbidites in the slope basin west of Hydrate Ridge, was studied at three core sites west of the small submarine canyon cut into the western flank of Hydrate Ridge (Goldfinger et al., 2008, 2012; Fig. 7). Cascadia cores 56PC/TC, $02 \mathrm{PC} / \mathrm{TC}$, and $01 \mathrm{KC}$ are all in the same basin and are within $4 \mathrm{~km}$ of each other. All Hydrate Ridge cores contain a relatively high silt content that is disseminated throughout even the hemipelagic units, making the distinction of mudsilt turbidites somewhat more difficult. We attribute this to the steep, sandy-silty cliffs exposed immediately to the east where seaward vergent thrust faulting uplifts Hydrate Ridge itself. We suggest these non-cohesive cliffs input a steady rain of sandy-silty material to the proximal basin floor. A similar relation is observed at proximal Sumatra sites.

Considering a cross-basin transect, the most proximal (furthest east) site to the steep cliff contains a late Holocene ( $\sim 3000 \mathrm{yr} \mathrm{BP}$ to modern) record in piston and trigger core $02 \mathrm{PC} / \mathrm{TC}$. The mid-basin site to the west (56PC/TC) contains a complete Holocene record with its base at $\sim 11000$ cal yr BP. The distal Kasten core site $(01 \mathrm{KC})$ may contain a partial Holocene record; however, radiocarbon age control to confirm Holocene stratigraphy was not possible owing to the poor preservation of thin hemipelagic clay intervals. The only ages obtained from this core are at the base of the section and are late Pleistocene (Fig. 7). No Mazama ash is present in any of the Hydrate Ridge cores, confirming the isolation of the Hydrate Ridge site from fluvial and possibly aerial sources. Core 56PC/TC shows among the best resolution of individual sand units within individual turbidites in existing Cascadia cores, most likely because of its proximal location. With little transport distance and time during transport for distinct inputs to mix following the initiating event, individual fining upward pulses remain more distinct (Goldfinger et al., 2007, 2012). Lithostratigraphic descriptions and correlation details are given in Goldfinger et al. (2012).

Given the robust correlations between cores $02 \mathrm{PC} / \mathrm{TC}$ and 56PC/TC (Fig. 7), source proximity generally controls turbidite thickness (Nelson et al., 1986). The section in proximal core $02 \mathrm{PC} / \mathrm{TC}$ is about twice the thickness of the equivalent section in core 56PC/TC. The compressed section of $01 \mathrm{KC}$ is further evidence of source proximity for control of sedimentation in Hydrate Ridge Basin West, likely exacerbated by the upslope position of the more distal core on the backlimb of the frontal thrust bounding the basin.

In Cascadia, turbidite channel systems help us in several ways. First, they provide the opportunity to sample different regions of the subduction zone. It is also only possible to use the confluence test of Adams (1990) with these linked channel systems. A downside of highly channelized systems is related to their ability to propagate turbidity currents. In some channel reaches, the channels are so efficient at promoting turbidity current flow that these reaches have evidence of turbidity current bypassing. Some Cascadia Channel cores, particularly just below the confluence with Willapa Channel, show these are areas of non-deposition (Griggs, 1968). Some areas of Willapa Channel have bare Pleistocene clay at the surface, showing turbidity current bypass of $100 \%$. A second example is lower Astoria Canyon that has gravel deposited in the thalweg and some bypassing of finer fractions, making levee sites better for turbidite deposition (Goldfinger et al., 2003). This is analogous to the evidence of bypassing found in the sedimentary systems offshore the Grand Banks following the earthquake in 1929 (Piper and Normark, 2009).

The turbidites in cores 12PC/TC and 23PC/TC are well correlated, evidenced by the detailed multi-pulse turbidite structures seen in Fig. 9c. 23PC/TC is $330 \mathrm{~km}$ downstream from $12 \mathrm{PC} / \mathrm{TC}$ and the correlations show that channel systems promote the long distance conveyance of turbidity currents, even with a low gradient such as that found in the Cascadia Channel system (Fig. 9). The channel gradients immediately upstream of $12 \mathrm{PC}$ and $23 \mathrm{PC}$ are $\sim 1^{\circ}$. This is reasonable given the flow velocity estimates of Griggs (1969) with 5.8 and $3.3 \mathrm{~m} \mathrm{~s}^{-1}$ in the upper and middle channels. That these turbidites share such detailed turbidite structure, when separated by $330 \mathrm{~km}$, spanning reaches of non-deposition, strengthens the argument that the turbidity currents maintain the seismogenic signal for large distances.

The Rogue Apron site has a somewhat higher hemipelagic-sedimentation rate (Goldfinger et al., 2012, 2013) compared to the other Cascadia cores and is also a proximal site at the foot of a steep continental slope. Cores 31PC/TC, 30PC/TC, and 01JC/TC form an unequally spaced E-W $7 \mathrm{~km}$ transect. In contrast to HRBW cores, the sedimentary section in $01 \mathrm{JC} / \mathrm{TC}$, the most distal core, is expanded by $\sim 5 \%$. This small expansion may be due to real variations in deposition or to variations in coring results (e.g. incorrect scope cable length, Skinner and McCave, 2003). One sedimentologic explanation would be that there was a hydraulic jump at the base of the slope, causing proximal cores to be bypassed leaving a thicker deposit at the distal core (Goldfinger et al., 2013), similar to the sedimentary response to the morphology offshore the 1929 Grand Banks earthquake (Piper and Normark, 2009). Variations in scope cable length can also change the magnitude of stratigraphic section compaction or extension (caused by over or under pressure from the piston system, Skinner and McCave, 2003).

\subsection{Cascadia and Sumatra, similarities and contrasts}

We discussed the factors that contributed to sedimentation of seismoturbidites along the subduction zone settings offshore of Sumatra and Cascadia. Slope basin cores along both margins suggest that turbidity currents are not as well organized in these proximal sites as currents in more distal or channel settings. Channels serve to confine and control flow, as well as serve as filters that allow passage of larger events, filtering out smaller ones, as well as amalgamating small complexities 
while apparently preserving significant elements of heterogeneity from the turbidity current. The evidence from more proximal cores is consistent with the preservation of greater inter-core variability in turbidite structure due mostly to the proximal setting. Similar observations have been made at the Hikurangi margin (Pouderoux et al., 2011), where cores MD-3002 and MD-3003 show how local processes strongly control depositional histories, as well as cores collected elsewhere (Summer et al., 2010).

The good stratigraphic correlation between Sumatra core sites isolated from each other, land sediment sources, and from other triggering mechanisms, coupled with compatible radiocarbon ages suggest that the most likely triggering mechanism is regional earthquakes. Uncorrelated events present at some sites may be due to random sediment failures or smaller local earthquakes. These uncorrelated turbidites are thin and have low mass with non-unique fingerprints, making it difficult to interpret their trigger origin.

The youngest turbidite in the northern Sumatra cores most likely triggered by the 26 December 2004 great SASZ $M_{\mathrm{w}}=$ 9.1-9.3 earthquake. This event triggered turbidity currents in multiple submarine drainage systems that left stratigraphic evidence in the form of multi-pulse turbidites in isolated slope basin and trench depocenters. Radiocarbon and ${ }^{210} \mathrm{~Pb}$ analyses support this conclusion.

The potential of basin sites was initially undervalued in Cascadia, when it was assumed that most turbidity currents of interest would be channelized flows. For this reason, basin sites in Cascadia are few. However during the Sumatra cruise, we were forced to core in slope basins for age control purposes due to the $\sim 4200 \mathrm{~m}$ depth of the CCD; this depth was everywhere exceeded in the trench. Analysis of the Sumatra basin cores and the Hydrate Ridge Basin West cores subsequently revealed the importance of the record of turbidites in these basins, which are commonly quite isolated and thus provide a turbidite record free of terrestrial turbidite sources. In Sumatra all but two basin cores (85PC/TC and 92PC/TC) are completely isolated from terrestrial sources of sedimentation; these two cores are possibly influenced by canyon systems linked to the forearc islands of Siberut and Nias. Cascadia Hydrate Ridge Basin West cores were originally collected in the interest of investigating slope failures related to hydrate destabilization, but were demonstrated to instead record earthquakes (Johnson et al., 2005; Goldfinger et al., 2012). Other cores (e.g. M9907-10PC) collected in the slope of Washington and Oregon did not have the high relief source area required to generate turbidity currents, as evidenced by the lack of turbidites in these cores (A. Mix, personal communication, 2012, also documented in non-channel areas by Carson, 1971 and Barnard and McManus, 1973).

Turbidite sedimentary systems along the margins of Sumatra and Cascadia provide different forcing factors, controlling the spatial likelihood of preserving and later correlating turbidites. Sumatra's margin is compromised by the lack of channel systems in the trench/abyssal plain, making most sites proximal and limiting the spatial extent for any given turbidite deposit. This makes it more difficult to distinguish and correlate the stratigraphic sequences. Cascadia's channel systems and shallow depth (for radiocarbon data) contribute to our ability to correlate seismoturbidites because the channels tend to promote low-frequency components of the content of the current over longer distances and have multiple branches, sampling different regional source areas. These channel sites are excellent locations to develop a stratigraphic framework, where more proximal slope basins and base-ofslope apron fan settings result in a turbidite structure that is more likely to be influenced by local physiography and other factors.

\section{Conclusions}

Based on correlation of similar sequences of individual turbidites between several depositional settings, earthquakes are a principal cause for turbidite deposition along slope and trench settings for the Cascadia and Sumatra-Andaman subduction zones during much or all of the Holocene. Source proximity, basin effects, turbidity current flow path, earthquake rupture patterns (both temporal and spatial), hydrodynamics, and topography all likely play roles in the construction of each turbidite as evidenced by the complex vertical structure of the final deposits.

Sedimentary systems in both Sumatra and Cascadia have been impacted by processes driven by climate and tectonics. These impacts from the Pleistocene are long lived and continue to have an effect on turbidity current flow paths. Basin records in Sumatra and Cascadia show that local topography has a dominant control on sedimentation, influencing the overall section thickness, the degree to which small local downslope movement will be recorded, the grain size profiles, and the recording fidelity of transport events. Very proximal sites in both settings appear to record much more detail, in some cases obscuring some components of the turbidite. Relatively more distal cores lose some detail but retain the main elements of seismoturbidites for significant distances down channel (Fig. 9b). "Distal" in this sense may be a matter of only a few km, as both Cascadia and Sumatra cores show strong sorting out of the chaotic proximal deposits into well-organized correlable deposits in distances as short as $1-3 \mathrm{~km}$.

Cascadia's margin is dominated by Pleistocene formed turbidity current channel pathways which promote turbidity current flows for large distances. Sumatra margin pathways do not inherit these sedimentary systems, so turbidity currents are more localized. The Sumatra margin lacks a locally sourced supply of sediment, thus there are no large fan systems affecting turbidity current transport in the trench. Bengal/Nicobar fan sediments extend from the shelf in the northern Bay of Bengal to at least the southern tip of Sumatra, but have not been active since the late Pleistocene (Moore 
et al., 1976; Weber et al., 2003) leaving few turbidity current sources other than earthquakes or random self-failures. Holocene hemipelagic sedimentation rates are lower in this equatorial location (Combes et al., 1999; Kahru et al., 2010), further contributing to the lack of large fans and sediment sources for sheet flow turbidites sourced on the slope. In Cascadia the regional draping of abyssal plain sedimentation on the incoming plate is sourced locally. In Sumatra, this sedimentation was originally sourced in the Himalayas to the North and is now sourced locally through recycling of accreted material in the accretionary prism. Because Bengal Fan sedimentation processes are no longer active in the Sumatra trench (Weber et al., 2003), the channel systems on the incoming plate are relict systems and disrupted by reactivated normal faults in the downgoing plate. The lack of trench axial channels (channels in the axis of the trench) retards the propagation of turbidity currents down trench, indicated by the strong relation between particle size and point sediment sources of the turbidity currents in the Sumatra trench.

The presence or absence of turbidite channel systems exerts a first order control on sedimentation in the trench in these two sedimentary systems. The absence of long trenchparallel channel systems in Sumatra is due to interruption by subducting features and a low sedimentation rate since at least the Pleistocene. These two factors appear to limit turbidity current transport in the trench. Cascadia basin has some channel systems, but also does not have a trench parallel transport system for a different reason; the trench is filled with the large Astoria and Nitinat fans and instead has channels that trend away from the major fan systems, out into Cascadia basin for long distances. Sites in the southern CSZ where there are no large fans tend to be small aprons or plunge pools, with more similarities to the Sumatra trench. In Sumatra the proximity to localized source areas exerts controls on the thickness and coarseness of turbidite deposits. In Cascadia, the cores and the $3.5 \mathrm{kHz}$ seismic data suggest that sheet flow mass wasting is more common near the base of the slope, accounting for greater consistency of the deposits.

Channel configuration controls the distance that turbidity currents can travel in Sumatra and Cascadia. Formed during low stands with high sediment discharge, Juan de Fuca and Cascadia Channel systems have rectangular cross sections which may tend to promote high flow velocities that maintain flows throughout this study area. In contrast, channel systems in Sumatra are limited in length or not detectable, so the down-trench flow propagation of coarse grained turbidity currents appears to be quite short. Turbidites in Cascadia show that both point source and sheet sources contribute to the sedimentary record in the trench (see also Goldfinger et al., 2013). Somewhat in contrast, turbidites in Sumatra suggest that point sources are more important with respect to the aerial distribution of turbidity currents.

Consistent reproduction of similar structure across depositional settings in both margins reinforces the need for a common source mechanism to explain the observed correlations. The best explanation of the observed consistency is an earthquake source. Both Cascadia and Sumatra turbidites show evidence of strong local influences on turbidite structure that are consistent with proximity to and type of locally sourced sediment failures. Variability is higher in proximal settings, but so also is the fidelity of recording details of the turbidity current. We interpret the effects to be superimposed on the initial longitudinal flow structure of the turbidity current, allowing observation of the influences of both the initial structure and the local modifications to each resulting turbidite. Long channel systems, more prevalent in Cascadia, tend to promote low-frequency components of the content of the current over longer distances with some loss of detail with distance.

\section{Supplement information}

For those interested in observing the core figures in greater detail, there is a higher resolution version of this paper available as a Supplement (117 MB file size).

\section{Supplementary material related to this article is available online at: http://www.nat-hazards-earth-syst-sci.net/13/833/2013/ nhess-13-833-2013-supplement.zip.}

Acknowledgements. This research was funded by the Ocean Sciences and Earth Sciences Divisions of the National Science Foundation. We thank M. Erhardt, Amy M. Garrett, and Robert H. Porter. for conducting lab analyses; NOC, IFREMER, and BGR for providing key bathymetry and sub-bottom data; UTM, for providing science crew; NOC for providing Russ Wynn; BGR for providing Stefan Ladage; and AIST/GSJ for providing Ken Ikehara. We also thank coring technicians from OSU including Chris Moser, Bob Wilson, Paul Walszak. Scripps Resident Technicians, the R/V Roger Revelle Captain Tom DesJardins and crew, and student volunteers and faculty from OSU including Bart DeBaere and Maureen Davies. Further details regarding the cruise and the core locations, please refer to the cruise report here: http://www.activetectonics. coas.oregonstate.edu/sumatra/report/index.html

J. R. P and C. G. led the discussion. J. R. P, C. G., A. M., and C. R. led fieldwork and lab analyses; B. B. and J. R. P. conducted seismologic processing and display; Y. D. and U. H. assisted in field work.

Edited by: E. Gràcia

Reviewed by: A. Meltzner and one anonymous referee 


\section{References}

Abdeldayem, A. L., Ikehara, K., and Yamazaki, T.: Flow Path of the 1993 Hokkaido-Nansei-Oki Earthquake Seismoturbidite, Southern Margin of the Japan Sea North Basin, Inferred from Anisotropy of Magnetic Susceptibility, Geophys. J. Int., 157, 1524, 2004.

Abrantes, F., Alt-Epping, U., Lebreiro, S., Voelker, A., and Schneider, R.: Sedimentological Record of Tsunamis on Shallow-Shelf Areas: The Case of the 1969 Ad and 1755 AD Tsunamis on the Portuguese Shelf Off Lisbon, Mar. Geol., 249, 283-293, 2008.

Adams, J.: Paleoseismicity of the Cascadia Subduction Zone: Evidence from Turbidites off the Oregon-Washington Margin, Tectonics, 9, 569-584, 1990.

Atwater, B. F.: Evidence for Great Holocene Earthquakes Along the Outer Coast of Washington State, Science, 236, 942-944, 1987.

Atwater, B. F. and Hemphill-Haley, E.: Recurrence Intervals for Great Earthquakes of the Past 3500 Years at Northeastern Willapa Bay, Washington, US Geological Survey Professional Paper, 1576, 108 pp., 1997.

Baas, J. H., McCaffrey, W. D., Haughton, P. D. W., and Choux, C.: Coupling between Suspended Sediment Distribution and Turbulence Structure in a Laboratory Turbidity Current, J. Geophys. Res., 110, 20 pp., 2005.

Bandopadhyay, A. and Bandopadhyay, R. R.: Thermogenic Hydrocarbons in the Mid-Proximal Bengal Fan, West of the AndamanNicobar Islands, Marine Geores. Geotech., 17, 1-16, 1999.

Beattie, P. D. and Dade, W. B.: Is Scaling in Turbidite Deposition Consistent with Forcing by Earthquakes, J. Sediment. Res., 66, 909-915, 1996.

Bilham, R.: Partial and Complete Rupture of the Indo-Andaman Plate Boundary 1847-2004, Seismol. Res. Lett., 76, 299-311, 2005.

Biscontin, G. and Pestana, J. M.: Factors affecting seismic response of submarine slopes, Nat. Hazards Earth Syst. Sci., 6, 97-107, doi:10.5194/nhess-6-97-2006, 2006.

Blott, S. J. and Pye, K.: Particle Size Distribution Analysis of SandSized Particles by Laser Diffraction: An Experimental Investigation of Instrument Sensitivity and the Effects of Particle Shape, Sedimentology, 53, 671-685, 2006.

Bock, Y., Prawirodirdjo, L., Genrich, J. F., Stevens, C. W., McCaffrey, R., Subarya, C., Puntodewo, S. S. O., and Calais, E.: Crustal Motion in Indonesia from Global Positioning System Measurements, J. Geophys. Res., 108, 2367, doi:10.1029/2001JB000324, 2003.

Bondevik, S., Svendsen, J. I., and Mangerud, J.: Tsunami Sedimentary Facies Deposited by the Storegga Tsunami in Shallow Marine Basins and Coastal Lakes, Western Norway, Sedimentology, 44, 1115-1131, 1997.

Bouma, A. H.: Sedimentology of Some Flysch Deposits, Elsevier Publishing, 168 pp., 1962.

Bouma, A. H.: Key Controls on the Characteristics of Turbidite Systems, Confined Turbidite System, Geological Society, London, Special Publications, 222, 9-22, 2004.

Bouma, A. H., Delery, A. M., and Benavides-lglesias, A.: Basin Characteristics, Tectonic History, and Grain Size Are Main Influences in the Transport and Deposition of Turbidity Currents, Gulf Coast Association of Geological Societies Transactions, 56, 103-118, 2006.
Bourget, J., Zaragosi, S., Ellouz-Zimmermann, S., Ducassou, E., Prins, M. A., Garlan, T., Lanfumey, V., Schneider, J.-L., Rouillard, P., and Giraudeau, J.: Highstand Vs. Lowstand Turbidite System Growth in the Makran Active Margin: Imprints of HighFrequency External Controls on Sediment Delivery Mechanisms to Deep Water Systems, Mar. Geol., 274, 187-208, 2010.

Bourget, J., Zargosi, S., Ellouz-Zimmermann, N., Mouchot, N., Garlans, T., Schneider, J., Lanfumey, V., and Lallemant, S.: Turbidite System Architecture and Sedimentary Processes Along Topographically Complex Slopes: The Makran Convergent Margin, Sedimentology, 58, 376-406, 2011.

Briggs, R. W., Sieh, K., Meltzner, A. J., Natawidjaja, D., Galetzka, J., Suwargadi, B., Hsu, Y., Simons, M., Hananto, N., Suprihanto, I., Prayudi, D., Avouac, J., Prawirodirdjo, L., and Bock, Y.: Deformation and Slip Along the Sunda Megathrust in the Great 2005 Nias-Simeulue Earthquake, Science, 311, 18971901, 2006.

Carlson, P. R.: Marine Geology of Astoria Submarine Canyon, Marine Geology, PhD Thesis, Oregon State University, 259 pp., 1967.

Carlson, P. R. and Nelson, C. H.: Sediments and Sedimentary Structures of the Astoria Submarine Canyon-Fan System, Northeast Pacific, Sediment. Petrol., 39, 1269-1282, 1969.

Carson, B.: Stratigraphy and depositional history of Quaternary sediments in northern Cascadia Basin and Juan de Fuca Abyssal Plain, northeast Pacific Ocean, Ph.D. dissert., Seattle, Univ. Washington, 249 pp., 1971.

Carter, R. M.: The Nature and Evolution of Deep-Sea Channel Systems, Basin Res., 1, 41-54, 1988.

Chaytor, J. D., Goldfinger, C., Dziak, R. P., and Fox, C. G.: Active Deformation of the Gorda Plate: Constraining Deformation Models with New Geophysical Data, Geology, 32, 353-356, 2004.

Chlieh, M., Avouac, J.-P., Hjorleifsdottir, V., Song, T.-R. A., Chen, J., Sieh, K., Sladen, A., Hebert, H., Prawirodirdjo, L., Bock, Y., and Galetzka, J.: Coseismic Slip and Afterslip of the Great (Mw 9.15) Sumatra-Andaman Earthquake of 2004, B. Seismol. Soc. Am., 97, S152-S173, 2007.

Chlieh, M., Avouac, J. P., Sieh, K., Natiwidjaja, D. H., and Galetzka, J.: Heterogeneous Coupling of the Sumatran Megathrust Constrained by Geodetic and Paleogeodetic Measurements, J. Geophys. Res., 113, 31 pp., 2008.

Combes, H. J. D., Caulet, J., and Tribovillard, N. P.: Pelagic Productivity Changes in the Equatorial Area of the Northwest Indian Ocean During the Last 400,000 Years, Mar. Geol., 158, 27-55, 1999.

Curray, J. R. and Moore, D. G.: Growth of the Bengal Deep-Sea Fan and Denudation in the Himalayas, GSA Bulletin, 82, 563572, 1971.

Curray, J. R., Emmel, F. J., and Moore, D. G.: The Bengal Fan: Morphology, Geometry, Stratigraphy, History and Processes, Marine Petrol. Geol., 19, 1191-1223, 2003.

Dallimore, A., Thomson, R. E., and Bertram, M. A.: Modern to Late Holocene Deposition in an Anoxic Fjord on the West Coast of Canada: Implications for Regional Oceanography, Climate and Paleoseismic History, Mar. Geol., 219, 47-60, 2005.

Duncan, R. A.: Late Pleistocene and Postglacial Sedimentation and Stratigraphy of Deep-Sea Environments off Oregon, Ph.D. thesis, 222 pp., 1968. 
Duncan, J. R. and Kulm, L. D.: Mineralogy, Provenance and Dispersal History of Late Quaternary Deep-Sea Sands in Cascadia Basin and Blanco Fracture Zone, J. Sediment. Petrol., 40, 874887,1970

Dziak, R. P., Fox, C. G., Bobbitt, A., and Goldfinger, C.: Bathymetric Map of the Gorda Plate: Structural and Geomorphological Processes Inferred from Mulitbeam Surveys, Marine Geophys. Res., 22, 235-250, 2001.

EEZ-SCAN-84-Scientific-Staff: Atlas of the Exclusive Economic Zone, Western Conterminous United States, 1986.

Fisher, D., Mosher, D., Austin, J. A., Gulick, S. P., Masterlark, T., and Moran, K.: Active Deformation across the Sumatran Forearc over the December 2004 Mw 9.2 Rupture, Geology, 35, 99-102, 2007.

Fukuma, K.: Origin and Applications of Whole-Core Magnetic Susceptibility of Sediments and Volcanic Rocks from Leg 152, Proceedings fo the Ocean Drilling Program: Scientific Results, 152, 271-280, 1998.

Fujiwara, O., Masuda, F., sakai, T., Irizuki, T., and Fuse, K., Tsunami Deposits in Holocene Bay Mud in Southern Kanto Region, Pacific Coast of Central Japan, Sediment. Geol., 135, 219230, 2000

Goldfinger, C.: Possible Turbidite Record of Earthquake Source Characteristics: A Small Scale Test, U.S.G.S. Final Technical Report, N.E.H.R.P. Award 07HQGR0064, 2011.

Goldfinger, C., Kulm, L. D., Yeats, R. S., Appelgate, B., MacKay, M., and Moore, G. F.: Transverse Structural Trends Along the Oregon Convergent Margin: Implications for Cascadia Earthquake Potential, Geology, 20, 141-144, 1992.

Goldfinger, C., Kulm, L. D., Yeats, R. S., Appelgate, B., MacKay, M., and Cochrane, G. R.: Active Strike-Slip Faulting and Folding of the Cascadia Plate Boundary and Forearc in Central and Northern Oregon, Assessing and Reducing Earthquake Hazards in the Pacific Northwest, Professional Paper 1560, 223-256, 1996.

Goldfinger, C., Kulm, L. D., Yeats, R. S., McNeill, L. C., and Hummon, C.: Oblique Strike-Slip Faulting of the Central Cascadia Submarine Forearc, J. Geophys. Res., 102, 8217-8243, 1997.

Goldfinger, C., Nelson, C. H., and Johnson, J. E.: Deep-Water Turbidites as Holocene Earthquake Proxies: The Cascadia Subduction Zone and Northern San Andreas Fault Systems, Ann. Geofis., 46, 1169-1194, 2003.

Goldfinger, C., Morey, A. E., Nelson, C. H., Gutierrez-Pastor, J., Johnson, J. E., Karabanov, E., Chaytor, J., and Ericsson, A.: Rupture Lengths and Temporal History of Significant Earthquakes on the Offshore and North Coast Segments of the Northern San Andreas Fault Based on Turbidite Stratigraphy, Earth Planet. Sci. Lett., 254, 9-27, 2007.

Goldfinger, C., Grijalva, K., Burgmann, R., Morey, A. E., Johnson, J. E., Nelson, C. H., Gutierrez-Pastor, J., Ericsson, A., Karabanov, E., Chaytor, J. D., Patton, J., and Gracia, E.: Late Holocene Rupture of the Northern San Andreas Fault and Possible Stress Linkage to the Cascadia Subduction Zone, B. Seismol. Soc. Am., 98, 861-889, 2008.

Goldfinger, C., Nelson, C. H., Morey, A., Johnson, J. E., GutierrezPastor, J., Eriksson, A. T., Karabanov, E., Patton, J., Gracia, E., Enkin, R., Dallimore, A., Dunhill, G., and Vallier, T.: Turbidite Event History: Methods and Implications for Holocene Paleoseismicity of the Cascadia Subduction Zone, USGS Professional
Paper \# 178, 2012a.

Goldfinger, C., Morey, A., Black, B., and Patton, J.: Spatially Limited Mud Turbidites on the Cascadia Margin: Segmented Earthquake Ruptures?, in: Research Conference Submarine Paleoseismology: The Offshore Search of Large Holocene Earthquakes: Obergurgl, edited by: Pantosti, D., Gracia, E., Lamarche, G., Nelson, C. H., and Tinti, S., Austria, 2012b.

Gorsline, D. S., De Diego, T., and Nava-Sanchez, E. H.: Seismically Triggered Turbidites in Small Margin Basins: Alfonso Basin, Western Gulf of California and Santa Monica Basin, California Borderland, Sediment. Geol., 135, 21-35, 2000.

Gràcia, E., Vizcaino, A., Escutia, C., Asioli, A., Rodés, Á., Pallàs, R., Garcia-Orellana, J., Lebreiro, S., and Goldfinger, C.: Holocene Earthquake Record Offshore Portugal (Sw Iberia): Testing Turbidite Paleoseismology in a Slow-Convergence Margin, Quaternary Sci. Rev., 29, 1156-1172, 2010.

Graindorge, D., Klingelhoefer, F., Sibuet, J., McNeill, L., Henstock, T. J., Dean, S., Gutscher, M., Dessa, J. X., Permana, H., Singh, S. C., Leau, H., White, N., Carton, H., Malod, J. A., Rangin, C., Aryawan, K. G., Chaubey, A. K., Chauhan, A., Galih, D. R., Greenroyd, C. J., Laesanpura, A., Prihantono, J., Royle, G., and Shankar, U.: Impact of Lower Plate Structure on Upper Plate Deformation at the Nw Sumatran Convergent Margin from Seafloor Morphology, Earth Planet. Sci. Lett., 275, 201-210, 2008.

Griggs, G. B., Carey, J. R. A. G., and Kulm, L. D.: Deep-Sea Sedimentation and Sediment-Fauna Interaction in Cascadia Channel and N Cascadia Abyssal Plain, Deep-Sea Res., 16, 157-170, 1969.

Gulick, S. P. S., Austin Jr., J. A., McNeill, L.C., Bangs, N. L. B., Martin, K. M., Henstock, T. J., Bull, J. M., Dean, S., Djadjadihardja, Y. S., and Permana, H.: Updip Rupture of the 2004 Sumatra Earthquake Extended by Thick Indurated Sediments, Nat. Geosci., 4, 453-456, 2011

Hagstrum, J. T., Atwater, B. F., and Sherrod, B. L.: Paleomagnetic Correlation of Late Holocene Earthquakes among Estuaries in Washington and Oregon, Geochem. Geophys. Geosyst., 5, Q10001, doi:10.1029/2004GC000736, 2004.

Hampton, M. A., Lee, H. J., and Locat, J.: Submarine Landslides, Rev. Geophys., 34, 33-59, 1996.

Henstock, T. J., McNeill, L. C., and Tappin, J. R.: Seafloor Morphology of the Sumatran Subduction Zone: Surface Rupture During Megathrust Earthquakes?, Geology, 34, 485-488, 2006.

Inouchi, Y., Kinugasa, Y., Kumon, F., Nakano, S., Yasumatsu, S., and Shiki, T.: Turbidites as Records of Intense Palaeoearthquakes in Lake Biwa, Japan, Sediment. Geol., 104, 117-125, 1996.

Ishii, M., Shearer, P. M., Houston, H., and Vidale, J. E.: Teleseismic P Wave Imaging of the 26 December 2004 SumatraAndaman and 28 March 2005 Sumatra Earthquake Ruptures Using the Hi-Net Array, J. Geophys. Res., 112, B11307, doi:10.1029/2006JB004700, 2007.

Johnson, J. E., Goldfinger, C., Trehu, A. M., Bangs, N. L. B., Torres, M. E., and Chevallier, J.: North-South Variability in the History of Deformation and Fluid Venting across Hydrate Ridge, Cascadia Margin, Proceedings of the Ocean Drilling Program; scientific results; drilling gas hydrates on Hydrate Ridge, Cascadia continental margin, covering Leg 204 of the cruises of the drilling vessel JOIDES Resolution, Victoria, British Columbia, Canada, 16 pp., 2005. 
Kahru, M., Gille, S. T., Murtugudde, R., Strutton, P. G., Manzano, M. S., Wang, H., and Mitchell, B. G.: Global Correlations between Winds and Ocean Chlorophyll, J. Geophys. Res., 115, C12040, doi:10.1029/2010JC006500, 2010.

Karlin, R. and Seitz, G.: A Basin Wide Record of Earthquakes at Lake Tahoe: Validation of the Earthquake Induced Turbidite Model with Sediment Core Analysis: Collaborative Research with UNR and SDSU, Final Technical Report for 07HQGR0014 and 07HQGR0008, 18 pp., 2007.

Karlin, R. E., Holmes, M., Abella, S. E. B., and Sylwester, R.: Holocene Landslides and a 3500-Year Record of Pacific Northwest Earthquakes from Sediments in Lake Washington, Geol. Soc. Am. Bull., 116, 94-108, 2004.

Keeper, D. K.: Landslides Caused by Earthquakes, GSA Bulletin, 95, 406-421, 1984.

Kneller, B. and McCaffrey, B.: Modeling the Effects of Salt-Induced Topography on Deposition from Turbidity Currents, Gulf Coast Section Society of Economic Paleontologists and Mineralogists Foundation Sixteenth annual research conference, 16, 137-145, 1995.

Kneller, B. C. and McCaffrey, W. D.: The Interpretation of Vertical Sequences in Turbidite Beds: The Influence of Longitudinal Flow Structure, J. Sediment. Res., 73, 706-713, 2003.

Kopp, H., Weinrebe, W., Ladage, S., Barckhausen, U., Klaeschen, D., Flueh, E. R., Gaedicke, C., Djajadihardja, Y., Grevemeyer, I., Krabbenhoeft, A., Papenbergn, C., and Zillmern, M.: Lower Slope Morphology of the Sumatra Trench System, Basin Res., 20, 519-529, 2008.

Krabbenhoeft, A., Weinrebe, R. W., Kopp, H., Flueh, E. R., Ladage, S., Papenberg, C., Planert, L., and Djajadihardja, Y.: Bathymetry of the Indonesian Sunda margin-relating morphological features of the upper plate slopes to the location and extent of the seismogenic zone, Nat. Hazards Earth Syst. Sci., 10, 1899-1911, doi:10.5194/nhess-10-1899-2010, 2010.

Kulm, L. D., Suess, E., Moore, J. C., Carson, B., Lewis, B. T., Ritger, S. D., Kadko, D. C., Thornburg, T. M., Embley, R. W., Rugh, W. D., Massoth, G. J., Langseth, M. G., Cochrane, G. R., and Scamman, R. L.: Oregon Subduction Zone: Venting Fauna and Carbonates, Science, 231, 561-566, 1986.

Ladage, S., Weinrebe, W., Gaedicke, C., Barckhausen, U., Flueh, E. R., Heyde, I., Krabbenhoeft, A., Kopp, H., Fajar, S., and Djardjardihardja, Y.: Bathymetric Survey Images Structure Off Sumatra, EOS Trans. AGU, 87, 2006.

Lorenzoni, L., Benitez-Nelson, C. R., Thunell, R. C., Hollander, D., Varela, R., Astor, Y., Audemard, F. A., and Muller-Karger, F. E.: Potential Role of Event-Driven Sediment Transport on Sediment Accumulation in the Cariaco Basin, Venezuela, Mar. Geol., 307310, 105-110, 2012a.

Lorenzoni, L., Thunell, R. C, Benitez-Nelson, C. R., Hollander, D., Martinez, N., Tappa, E., Varela, R., Astor, Y., and MullerKarger, F. E.: The Importance of Subsurface Nepheloid Layers in Transport and Delivery of Sediments to the Eastern cariaco basin, Venezuela, Deep-Sea Res. Part I, 56, 2249-2262, 2012 b.

Lovlie, R. and Van Veen, P.: Magnetic Susceptibility of a 180 M Sediment Core: Reliability of Incremental Sampling and Evidence for a Relationship between Susceptibility and Gamma Activity, Palaeomagnetic Applications in Hydrocarbon Exploration and Production, 259-266, 1995.
Malik, J. N., Shishikura, M., Echigo, T., Ikeda, Y., Satake, K., Kayanne, H., Sawai, Y., Murty, C. V. R., and Dikshit, D.: Geologic Evidence for Two Pre-2004 Earthquakes During Recent Centuries near Port Blair, South Andaman Island, India, Geology, 39, 559-562, 2011.

Masson, D. G., Harbitz, C. B., Wynn, R. B., Pedersen, G., and Løvholt, F.: Submarine Landslides: Processes, Triggers and Hazard Prediction, Philos. Trans. Roy. Soc., 364, 2009-2039, 2006.

McCaffrey, R., Qamar, A., King, R. W., Wells, R. W., Khazaradze, G., Williams, C., Stevens, C., Vollick, J. J., and Zwick, P. C.: Fault Locking, Block Rotation and Crustal Deformation in the Pacific Northwest, Geophys. J. Int., 1-26, doi:10.1111/j.1365246X.2007.03371.x, 2007.

McCalpin, J. P. and Nelson, A. R.: Introduction to Paleoseismology, Paleoseismology, 62, 1-32, 1996.

McNeill, L. C., Goldfinger, C., Kulm, L. V. D., and Yeats, R. S.: Tectonics of the Neogene Cascadia Forearc Basin: Investigations of a Deformed Late Miocene Unconformity, B. Geol. Soc. Am., 112, 1209-1224, 2000.

Meltzner, A. J., Sieh, K., Chiang, H., Shen, C., Suwargadi, B. W., Natawidjaja, D. H., Philbosian, B., Briggs, R. W., and Galetzka, J.: Coral Evidence for Earthquake Recurrence and an A.D. 13901455 Cluster at the South End of the 2004 Aceh-Andaman Rupture, J. Geophys. Res., 115, 1-46, 2010.

Meltzner, A. J., Sieh, K., Chiang, H., Shen, C., Suwargadi, B. W., Natawidjaja, D. H., Philibosian, B., and Briggs, R. W.: Persistent Termini of 2004- and 2005-Like Ruptures of the Sunda Megathrust, J. Geophys. Res., 117, B04405, doi:10.1029/2011JB008888, 2012.

Meunier, P., Hovius, N., and Haines, A. J.: Regional Patterns of Earthquake-Triggered Landslides and Their Relation to Ground Motion, Geophys. Res. Lett., 34, L20408, doi:10.1029/2007GL031337, 2007.

Moore, D. G., Curray, J. R., and Emmell, F. J.: Large Submarine Slide (Olistostrome) Associated with Sunda Arc Subduction Zone, Northeast Indian Ocean, Mar. Geol., 21, 211-226, 1976.

Mosher, D. C. and Piper, D.: Analysis of Multibeam Seafloor Imagery of the Laurentian Fan and the 1929 Grand Banks Landslide Area, Adv. Nat. Technol. Haz., 3rd international symposium, 27, 77-88, 2007.

Mosher Jr., D. C., Austin, J. A., Fisher, D., and Gulick, S. P. S.: Deformation of the Northern Sumatra Accretionary Prism from High-Resolution Seismic Reflection Profiles and ROV Observations, Mar. Geol., 252, 89-99, 2008.

Mosher, D. C., Moscardelli, L., Shipp, R. C., Chaytor, J. D., Baxter, C. D. P., Lee, H. J., and Urgeles, R.: Submarine Mass Movements and Their Consequences, Adv. Nat. Technol. Haz., 28, 1-8, 2010.

Mulder, T., Syvitski, J. P. M., Migeon, S., Faugeres, J., and Savoye, B.: Marine Hyperpycnal Flows; Initiation, Behavior and Related Deposits; a Review, Marine Petrol. Geol., 20, 861-882, 2003.

Nakajima, T.: Initiation Processes of Turbidity Currents; Implications for Assessments of Recurrence Intervals of Offshore Earthquakes Using Turbidites, B. Geol. Survey Jpn., 51, 79-87, 2000.

Nakajima, T. and Kanai, Y.: Sedimentary Features of Seismoturbidites Triggered by the 1983 and Older Historical Earthquakes in the Eastern Margin of the Japan Sea, Sediment. Geol., 135, 1-19, 2000.

Natawidjaja, D. H., Sieh, K., Ward, S. N., Cheng, H., Edwards, R. L., Galetzka, J., and Suwargadi, B. W.: Paleogeode- 
tic Records of Seismic and Aseismic Subduction from Central Sumatran Microatolls, Indonesia, J. Geophys. Res., 109, B04306, doi:10.1029/2003JB002398, 2004.

Nelson, C. H., Carlson, P. R., and Bacon, C. R.: The Mount Mazama Climactic Eruption ( 6900 Yr B.P.) and Resulting Convulsive Sedimentation on the Crater Lake Caldera Floor, Continent, and Ocean Basin, Geol. Soc. Am., Special Paper 229, 37-57, 1988.

Nelson, A. R., Kelsey, H. M., and Witter, R. C.: Great Earthquakes of Variable Magnitude at the Cascadia Subduction Zone, Quaternary Res., 65, 354-365, 2006.

Nelson, C. H., Escutia, C., Goldfinger, C., Karabanov, E., GutierrezPastor, J., and DeBatist, M.: External Controls on Modern Clastic Turbidite Systems: Three Case Studies, Soc. Sediment. Geol., 92, 57-76, 2009.

Nelson, C. H., Escutia, C., Damuth, J. E., and Twichell, D. C.: Interplay of Mass-Transport and Turbidite-System Deposits in Different Active Tectonic and Passive Continental Margin Settings: External and Local Controlling Factors, Soc. Sediment. Geol., 96, 39-66, 2011.

Nelson, C. H., Kulm, L. D., Carlson, P. R., and Duncan, J. R.: Mazama Ash in the Northeastern Pacific, Science, 161, 47-49, 1968.

Nelson, C. H., Meyer, A. W., Thor, D., and Larsen, M.: Crater Lake, Oregon: A Restricted Basin with Base-of-Slope Aprons of Nonchanellized Turbidites, Geology, 14, 238-241, 1986.

Nelson, C. H., Hampton, M. A., Karl, H. A., and Barber Jr., J. H.: Astoria Fan, a Trench-Filling Elongate Deep-Sea Fan, Tectonics, sedimentation and evolution of the Eel River and associated coastal basins of Northern California, Misc. Publication, 37, 113-120, 1987.

Nelson, C. H., Goldfinger, C., Johnson, J. E., and Dunhill, G.: Variation of Modern Turbidite Systems Along the Subduction Zone Margin of Cascadia Basin and Implications for Turbidite Reservoir Beds, Deep-water Reservoirs of the World, 31 pp., 2000.

Nelson, C. H.: Marine Geology of the Astoria Deep-Sea Fan, Ph.D. thesis, Oregon State University, 1968.

Nelson, H.: Late Pleistocene and Holocene Depositional Trends, Processes and History of Astoria Deep-Sea Fan, Mar. Geol., 20, 129-173, 1976.

Newcomb, K. R. and McCann, W. R.: Seismic History and Seismotectonics of the Sunda Arc, J. Geophys. Res., 92, 421-439, 1987.

Ni, S., Kanamori, H., and Helmberger, D.: Energy Radiation from the Sumatra Earthquake, Nature, 434, p. 582, 2005.

Noda, A., Katayama, H., Sagayama, T., Suga, K., Uchida, Y., Satake, K., Abe, K., and Okamura, Y.: Evaluation of Tsunami Impacts on Shallow Marine Sediments: An Example from the Tsunami Caused by the 2003 Tokachi-Oki Earthquake, Northern Japan, Sediment. Geol., 200, 314-327, 2007.

Noller, J. S.: Lead-210 Geochronology, in: Quaternary Geochronology, edited by: Noller, J. S., Sowers, J. M., and Lettis, W. R., AGU Reference Shelf 4, 115-120, 2000.

Normark, W. R. and Reid, J. A.: Extensive Deposits on the Pacific Plate from Late Pleistocene North American Glacial Lake Outbursts, J. Geol., 222, 617-637, 2003.

Ortiz, M. and Bilham, R.: Source Area and Rupture Parameters of the 31 December $M_{\mathrm{W}}=7.9$ Car Nicobar Earthquake Estimated from Tsunamis Recorded in the Bay of Bengal, J. Geophys. Res., 108, 2215, doi:10.1029/2002JB001941, 2003.
Passega, R.: Texture as Characteristic of Clastic Deposition, AAPG Bull., 41, 1952-1984, 1957.

Passega, R.: Grain Size Representation by CM Patterns as a Geological Tool, J. Sediment. Petrol., 34, 830-847, 1964.

Piper, D. J. W.: Turbidite muds and silts on deepsea fans and abyssal plains, in: Sedimentation in Submarine Canyons, Fans and Trenches, edited by: Stanley, D. J. and Kelling, G., Stroudsburg, PA (Dowden, Hutchinson and Ross), 163-175, 1978.

Piper, D. J. W. and Normark, W. R.: Processes That Initiate Turbidity Currents and Their Influence on Turbidites: A Marine Geology Perspective, J. Sediment. Res., 79, 347-362, 2009.

Pouderoux, H., Proust, J., Lamarche, G., Orpin, A., and Neil, H.: Postglacial (after $18 \mathrm{Ka}$ ) Deep-Sea Sedimentation Along the Hikurangi Subduction Margin (New Zealand): Characterisation, Timing and Origin of Turbidites, Mar. Geol., 295-298, 51-76, 2012.

Prell, W. L., Imbrie, J., Martinson, D. G., Morley, J. J., Pisias, N. G., Shackleton, N. J., and Streeter, H. F.: Graphic Correlation of Oxygen Isotope Stratigraphy Application to the Late Quaternary, Paleoceanography, 1, 137-162, 1986.

Rajendran, K., Rajendran, C. P, Earnest, A., Ravi Prasad, G. V., Dutta, K., Ray, D. K., and Anu, R.: Age Estimates of Coastal Terraces in the Andaman and Nicobar Islands and Their Tectonic Implications, Tectonophysics, 455, 52-60, 2008.

Reid, J. A. and Normark, W. R.: Tufts Submarine Fan: TurbidityCurrent Gateway to Escanaba Trough, USGS Bulletin 2216, 26 pp., 2003.

Reimer, P. J., Baillie, M. G. L., Bard, E., Bayliss, A., Beck, J. W., Bertrand, C. J. H., Blackwell, P. G., Ramsey, C. B., Buck, C. E., Burr, G. S., Edwards, R. L., Friedrich, M., Grootes, P. M., Guilderson, T. P., Hajas, I., Heaton, T. J., Hogg, A. G., Hughen, K. A., Kaiser, K. F., Kromer, B., McCormac, F. G., Manning, S. W., Reimer, R. W., Richards, D. A., Southon, J. R., Talamo, S., van der Plicht, J., and Weyhenmeyer, C. E.: Intcal09 and Marine09 Radiocarbon Age Calibration Curves, 0-50,000 Years Cal Bp, Radiocarbon, 51, 1111-1150, 2009.

Salisbury, M., Patton, J., Kent, A., Goldfinger, C., Djadjadihardja, Y., and Udrekh, U.: Newly Discovered Deep-Sea Ash Layers Reveal Evidence of Large Holocene Volcanic Eruptions from Sumatra, Indonesia, J. Volcanol. Geoth. Res., 231-232, 61-71, 2012.

Sanders, J. E.: Primary Sedimentary Structures Formed by Turbidity Currents and Related Resedimentation Mechanisms, Primary Sediment. Struct. Hydr. Interpr., 12, 192-219, 1965.

Shanmugam, G.: The Constructive Functions of Tropical Cyclones and Tsunamis on Deep-Water Sand Deposition During Sea Level Highstand: Implications for Petroleum Exploration, AAPG Bulletin, 92, 443-471, 2008.

Shiki, T., Kumon, F., Inouchi, Y., Kontani, Y., Sakamoto, T., Tateishi, M., Matsubara, H., and Fukuyama, K., Sedimentary Features of the Seismo-Turbidites, Lake Biwa, Japan, Sediment. Geol., 135, 37-50, 2000.

Shirai, M., Omura, A., Wakabayashi, T., Uchida, J., and Ogami, T., Depositional Age and Triggering Event of Turbidites in the Western Kumano Trough, Central Japan During the Last Ca. 100 Years, Mar. Geol., 271, 225-235, 2010.

Sieh, K.: Sumatran Megathrust Earthquakes: From Science to Saving Lives, Philos. Trans. Roy. Soc., 364, 1947-1963, 2006. 
Sieh, K. and Natawidjaja, D.: Neotectonics of the Sumatran Fault, J. Geophys. Res., 105, 28295-28326, 2000.

Singh, S. C., Hananto, N. D., Chauhan, A. P. S., Permana, H., Denolle, M., Hendriyana, A., and Natawidjaja, D.: Evidence of Active Backthrusting at the Ne Margin Ofmentawai Islands, Swsumatra, Geophys. J. Int., 180, 703-714, 2010.

Skinner, L. C. and McCave, I. N.: Analysis and Modeling of Gravity- and Piston Coring Based on Soil Mechanics, Mar. Geol., 199, 181-204, 2003.

Smith, W. H. F. and Sandwell, D. T.: Global Seafloor Topography from Satellite Altimetry and Ship Depth Soundings, Science, 277, 1957-1962, 1997.

Stein, S. and Okal, E.: Ultralong Period Seismic Study of the December 2004 Indian Ocean Earthquake and Implications for Regional Tectonics and the Subduction Process, B. Seismol. Soc. Am., 97, S279-S295, 2007.

Sternberg, R. W.: Transport and Accumulation of River-Derived Sediment on the Washington Continental Shelf, J. Geol. Soc. London, 143, 945-956, 1986.

St-Onge, G., Mulder, T., Piper, D. J. W., Hillaire-Marcel, C., and Stoner, J. S.: Earthquake and Flood-Induced Turbidites in the Saguenay Fjord (Québec): A Holocene Paleoseismicity Record, Quaternary Sci. Rev., 23, 283-294, 2004.

St-Onge, G., Chapron, E., Mulsow, S., Salas, M., Viel, M., Debret, M., Foucher, A., Mulder, T., Winiarski, T., Desmet, M., Costa, P. J. M., Ghaleb, B., Jaouen, A., and Locat, J., Comparison of Earthquake-Triggered Turbidites from the Saguenay (Eastern Canada) and Reloncavi (Chilean Margin) Fjords: Implications for Paleoseismicity and Sedimentology, Sediment. Geol., 243244, 89-107, 2011.

Stow, D. A. V., Amano, K., Balson, P. S., Brass, G. W., Corrigan, J., Raman, C. V., Tiercelin, J.-J., Townsend, M., and Ijayananda, N. P.: Affiliation: Geol Dept, The Univ Southampton S. O. N. H. U. K, edited by: Cochran, J. R., Curray, J. R., Sager, W. W., and Stow, D. A. V., Sediment Facies and Processes on the Distal Bengal Fan, Leg 116, 377-396, in: Proc. scientific results, ODP, Leg 116, distal Bengal Fan (1990), 377-396, 1990.

Stow, D. A. V. and Piper, D. J. W.: Deep-Water Fine-Grained Sediments: Facies Models, Fine-Grained Sediments: Deep-Water Processes Facies, 611-646, 1984.

Strasser, M., Anselmetti, F. S., Fäh, D., Giardini, D., and Schnellmann, M.: Magnitudes and Source Areas of Large Prehistoric Northern Alpine Earthquakes Revealed by Slope Failures in Lakes, Geology, 34, 1005-1008, 2006.

Stuiver, M. and Braziunas, T. F.: Modeling Atmospheric ${ }^{14} \mathrm{C}$ Influences and ${ }^{14} \mathrm{C}$ Ages of Marine Samples to $10,000 \mathrm{Bc}$, Radiocarbon, 35, 137-189, 1993.

Stuiver, M. and Polach, H. A.: Discussion: Reporting of ${ }^{14} \mathrm{C}$ Data, Radiocarbon, 19, 355-363, 1977.

Stuiver, M., Reimer, P. J., and Braziunas, T. F.: High Precision Radiocarbon Age Calibration for Terrestrial and Marine Samples, Radiocarbon, 40, 1127-1151, 1998.
Subarya, C., Chlieh, M., Prawirodirdjo, L., Avouac, J., Bock, Y., Sieh, K., Meltzner, A. J., Natawidjaja, D. H., and McCaffrey, R.: Plate-Boundary Deformation Associated with the Great Sumatra-Andaman Earthquake, Nature, 440, 46-51, 2006.

Sugawara, D., Minoura, K., Nemoto, N., Tsukawaki, S., Goto, K., and Imamura, F.: Foraminiferal Evidence of Submarine Sediment Transport and Deposition by Backwash During the 2004 Indian Ocean Tsunami, Island Arc, 13 pp., 2009.

Summer, E., Siti, M., McNeill, L. C., Talling, P. J., Wynn, R., Henstock, T., Djardihardja, Y., and Permana, H.: Testing the Validity of Using Turbidites as an Earthquake Proxy on the Sumatran Margin, Abstract T11d-2129, Fall Meeting, AGU, San Francisco, Calif., 13-17 Dec., 2010.

Susilohadi, S., Gaedickea, C., and Ehrhardt, A.: Neogene Structures and Sedimentation History Along the Sunda Forearc Basins Off Southwest Sumatra and Southwest Java, Mar. Geol., 219, 133$154,2005$.

Thompson, R., Battarbee, R. W., O'Sulliuan, P. E., and Oldfield, F.: Magnetic Susceptibility of Lake Sediments, Limnol. Oceanogr., 20, 687-698, 1975.

Tolstoy, M. and Bohnenstiehl, D. R., Hydroacoustic Contributions to Understanding the December 26th 2004 Great SumatraAndaman Earthquake, Surv. Geophys., 27, 633-646, 2006.

Underwood, M. B., Hoke, K. D., Fisher, A. T., Davis, E. E., Giambalvo, E., Hlsdorff, L. Z., and Spinelli, G. A.: Provenance, Stratigraphic Architecture, and Hydrogeologic Influence of Turbidites on the Mid-Ocean Ridge Flank of Northwestern Cascadia Basin, Pacific Ocean, J. Sediment. Res., 75, 149-164, 2005.

van den Bergh, G. D., Boer, W., de Haas, H., van Weering, T. C. E., and van Wijhe, R.: Shallow Marine Tsunami Deposits in Teluk Banten (Nw Java, Indonesia), Generated by the 1883 Krakatau Eruption, Mar. Geol., 197, 13-34, 2003.

Wang, W. and Davis, D. M.: Sandbox Model Simulation of Forearc Evolution and Noncritical Wedges, J. Geophys. Res., 101, 11329-11339, 1996.

Wang, K. and $\mathrm{Hu}$, Y.: Accretionary Prisms in Subduction Earthquake Cycles: The Theory of Dynamic Coulomb Wedge, J. Geophys. Res., 111, B06410, doi:10.1029/2005JB004094, 2006.

Weber, M. E., Erlenkeuser, H., Wiedicke-Hombach, M., and $\mathrm{Ku}-$ drass, H. R.: Bengal Fan Sediment Transport Activity and Response to Climate Forcing Inferred from Sediment Physical Properties, Sediment. Geol., 155, 361-381, 2003.

Westbrook, G. K., Carson, B., and Party, Shipboard Scientific: Summary of Cascadia Drilling Results, Proceedings of the Ocean Drilling Program, Initial Reports, 146 (Part 1), 389-396, 1994.

Wolf, S. C., Nelson, C. H., Hamer, M. R., Dunhill, G., and Phillips, R. L.: The Washington and Oregon Mid-Shelf Silt Deposit and Its Relation to the Late Holocene Columbia River Sediment Budget, USGS Open File Report 99-173, 1999. 